\title{
THE ANCYLUS TRANSGRESSION IN THE AREA OF ESPOO - THE FIRST SALPAUSSELKÄ, SOUTHERN FINLAND
}

\author{
O. RISTANIEMI and G. GLÜCKERT
}

RISTANIEMI, O. and GLÜCKERT, G., 1987: The Ancylus transgression in the area of Espoo - the First Salpausselkä, southern Finland. Bull. Geol. Soc. Finland 59. Part 1, 45-69.

The extent and age of the Ancylus transgression was studied by means of shore marks in the field, biostratigraphy from 39 bog and lake basins, and radiocarbon determinations in the area of the Salpausselkä zone, west of Helsinki, southern Finland.

The rapid Yoldia regression in the Baltic from 10200 to $9700 \mathrm{BP}$ was followed by the Ancylus transgression, involving a rise in water level in the research area of 4-7 m. Evidence of this rise is seen in eight basins, and in loss on ignition and diatoms. The duration of the transgression was dated to the Betula pollen zone, from $9700-9500$ to $9200-9000 \mathrm{BP}$. According to the present material, the Ancylus transgression is visible in SW Finland as far as the zone of the Third Salpausselkä. This culmination zone of the transgression has earlier been marked as the $\mathrm{O}$ isobase.

The Betuna/Pinus (P) pollen zone boundary and the duration of the transgression were dated with the radiocarbon method and pollen analysis. The dispersion of the radiocarbon and pollen analytical dates might be caused by sources of error in the transgression sediment, such as mixing of the material and the abundance of secondary, older material. Moreover, the transgression began at different times in each basin, mainly depending on the altitude of the threshold of the basins. The date commonly used, $9000 \mathrm{BP}$, for pollen zone boundary P in southern Finland seems to be metachronous within the study area, and is probably so throughout southern Finland. Furthermore, zone boundary $\mathrm{P}$ has been dated to $9300-9200 \mathrm{BP}$ within the study area, and is thus a little older than proposed earlier.

Key words: changes of level, Ancylus Lake, lithostratigraphy, biostratigraphy, pollen diagrams, diatom flora, absolute age, Holocene, Finland, Espoo, Vihti, Lohja.

Olli Ristaniemi: Regional Planning Association of Vaasa Province, Vaasanpuistikko 20 B, Pl. 289, SF 65101 Vaasa, Finland.

Gunnar Glückert: Department of Quaternary Geology, University of Turku, SF 20500 Turku, Finland.

\section{Introduction}

Three transgressions have been observed during the Late glacial and postglacial history of the Baltic: at the beginning of the Baltic Ice Lake, Ancylus Lake and Litorina Sea stages. The first observations of a transgression in the Baltic at the beginning of the Ancylus Lake 


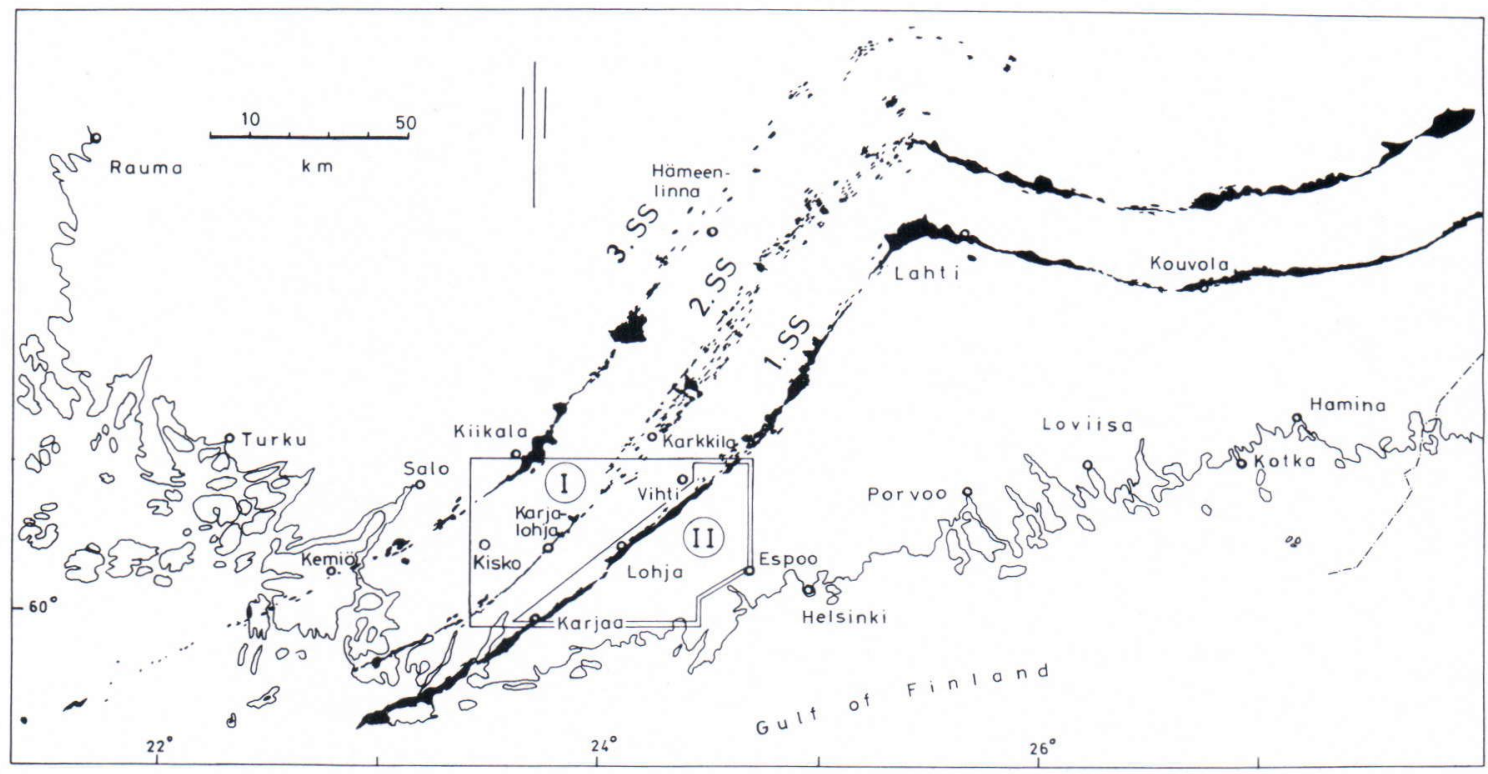

Fig. 1. The area studied for the present paper (II) is a part of the whole area studied in 1979-1982 (I).

stage were presented by Hyyppä (1932, 1937, 1942) from the Karelian Isthmus and southern Finland. Later, in investigations by Salmi (1948), Donner (1952) and Sauramo (1953, 1954, 1958), the transgression, dated to pollen analytical zone boundary IV/V, was termed the Echineis - Ancylus transgression. This theory was accepted by Valovirta (1965) and Tynni (1966). Eronen (1976), however, estabilished that only one transgression - the Ancylus transgression - occurred in southern Finland at zone boundary IV/V. This finding has been verified by more recent investigations from southern Finland (e.g. Glückert and Ristaniemi 1980, 1982; Eronen and Haila 1982; Haila 1982; Ristaniemi 1984).

The main topic of the latest investigations on the Ancylus Lake has been the transgression at the beginning of the lake phase. This paper deals with the water level fluctuations of the Baltic at the beginning of the Ancylus Lake stage. They have been studied in eight basins situated in the southern part of the study area, between Espoo and the First Salpausselkä (Fig.
1. II area). Altogether 39 basins were studied in 1979-1982 (I in Fig. 1). This study was part of the sea level project of IGCP. No. 61, and was financed by the Academy of Finland (Figs. 1 and 2).

\section{Investigation methods}

Lithostratigraphic investigation of lake and bog sediments is necessary when studying shore level displacement and especially the course of a transgression. The sampling sites and the lake and bog basins were chosen from the base maps at 1:20 000, so that the altitudes of their thresholds was somewhat lower than that of the Ancylus limit: this lies between 63 and $70 \mathrm{~m}$ in the southeastern part of the study area (e.g. Sauramo 1958; Glückert 1970). The levels of the basins and thresholds were estimated from the base maps or measured with a Thommen barometer to an accuracy of $\pm 1 \mathrm{~m}$ (Table 1). 
BASIN

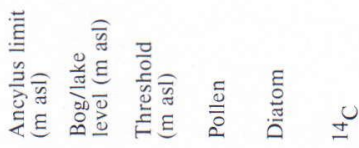

NOTES

PUBLICATIONS

1. Kuuslammi, Pertteli

2. Saarikkosuo, Suomusjärvi

3. Vesiontteenmäensuo, Suomusjärvi

4. Kukutin, Suomusjärvi

5. Lemikjärvi, Kisko

6. Iloittu, Nummi-Pusula

7. Tytlampi, Sammatti

8. Sorvalammi, Nummi-Pusula

9. Lammisto I, Kisko

10. Lammisto II, Kisko

11. Kaksoslammet, Kisko

12. Perälammi, Kisko

13. Kaksoislammet, Karjalohja

14. Kakarlampi I, Karjalohja

15. Kakarlampi II, Karjalohja

16. Innonlampi, Sammatti

17. Kaitalampi, Lohja mlk

18. Särkijärvi, Karjalohja

19. Iilampi, Karjalohja

20. Lehmälampi, Karjalohja

21. Keihilampi, Sammatti

22. Marjasuo, Lohja mlk

23. Teeressuo, Vihti

24. Otalampi, Vihti

25. Brännträsk, Siuntio

26. Svartträsk, Siuntio

27. Ahvenlampi, Espoo

28. Oralampi, Espoo

29. Rämesuo, Espoo

30. Myllyjärvi, Lahnus, Espoo

31. Myllyjärvi, Gunnars, Espoo

32. Suonsilmä, Lohja

33. Lakiassuo, Vihti

34. Myllyjärvet, Siuntio

35. Lull-Lampi, Espoo

36. Kaitlampi, Espoo

37. Luuk, Espoo

38. Kakarlampi, Espoo

39. Kaliton, Espoo

$\begin{array}{lllll}82 & 77 & 80 & x & x\end{array}$

$8281 \quad 80-x$

$\begin{array}{llll}81 & 73.5 & 74 & x\end{array}$

$\begin{array}{lll}80 & 80.1 \quad 82\end{array}$

$\begin{array}{llll}78 & 74 & 75 & \mathrm{x}\end{array}$

$\begin{array}{llll}78 & 75.3 & 76 & x\end{array}$

$\begin{array}{lll}77 & 73.4 & 74\end{array}$

$\begin{array}{lll}76 & 58.2 \quad 60\end{array}$

$\begin{array}{lll}76 & 71 & 72\end{array}$

$\begin{array}{lll}76 & 72 & 72\end{array}$

$\begin{array}{lll}77 & 75.3 & 76\end{array}$

$\begin{array}{lll}76 & 71.1 & 72\end{array}$

$\begin{array}{lll}74 & 68.1 \quad 69\end{array}$

$\begin{array}{lll}74 & 86.1 \quad 86\end{array}$

$\begin{array}{lll}75 & 69 & 70\end{array}$

$\begin{array}{lll}75 & 73.9 & 74\end{array}$

$\begin{array}{lll}73 & 67.2 & 68\end{array}$

$\begin{array}{lll}74 & 48.2 & 49\end{array}$

$\begin{array}{lll}73 & 53.8 & 54\end{array}$

$\begin{array}{lll}74 & 71.2 & 72\end{array}$

$\begin{array}{lll}74 & 72.6 & 73\end{array}$

$\begin{array}{lll}73 & 64 & 64\end{array}$

$\begin{array}{lll}71 & 66 & 67\end{array}$

$\begin{array}{lll}69 & 66.4 & 68\end{array}$

$\begin{array}{lll}68 & 59.0 & 59\end{array}$

$\begin{array}{lll}67 & 64.0 & 65\end{array}$

$\begin{array}{lll}65 & 64.6 & 68\end{array}$

$\begin{array}{lll}65 & 63.3 & 64\end{array}$

$\begin{array}{lll}65 & 63 & 64\end{array}$

$\begin{array}{lll}65 & 57.9 & 58\end{array}$

$\begin{array}{lll}64 & 58.1 & 59\end{array}$

$\begin{array}{lll}69 & 61.7 & 62\end{array}$

$\begin{array}{lll}69 & 69 & 67\end{array}$

$\begin{array}{lll}67 & 61.7 & 62\end{array}$

$\begin{array}{lll}64 & 59.7 & 60\end{array}$

$\begin{array}{lll}64 & 68 & 68\end{array}$

$\begin{array}{lll}64 & 63 & 62\end{array}$

$\begin{array}{lll}63 & 57.0 & 57\end{array}$

$\begin{array}{lll}62 & 60.2 & 61\end{array}$ isolation in B from A Ristaniemi 1984

hiatus

isolation in $\mathrm{B}$ from $\mathrm{Y}$ isolation in $\mathrm{B} / \mathrm{P}, \mathrm{Y} / \mathrm{A}$

hiatus

isolation in B from A isolation in $\mathrm{P}$ from $\mathrm{A}$ isolation in $\mathrm{B} / \mathrm{P}, \mathrm{Y} / \mathrm{A}$ isolation in $\mathrm{B}$ from $\mathrm{A}$ transgression

isolation in $\mathrm{B} / \mathrm{P}, \mathrm{Y} / \mathrm{A}$

isolation in $\mathrm{B} / \mathrm{P}, \mathrm{Y} / \mathrm{A}$

isolation in $\mathrm{B}$ from $\mathrm{Y}$

isolation in $\mathrm{P}$ from $\mathrm{A}$

hiatus

hiatus

isolation in $\mathrm{P}$ from $\mathrm{A}$ isolation in $\mathrm{P}$ from $\mathrm{A}$

transgression

transgression

hiatus

hiatus

hiatus

hiatus

hiatus

hiatus

hiatus

hiatus

hiatus

isolation in $\mathrm{P}$ from $\mathrm{A}$

isolation in $\mathrm{P}$ from $\mathrm{A}$

transgression

transgression?

transgression?

isolation in B from $Y$

transgression

transgression

transgression

Sauramo 1953, 1954, 1958

Mölder, Valovirta and

Virkkala 1957

$\mathrm{B}=$ Betula zone $\quad \mathrm{Y}=$ Yoldia stage

$\mathrm{P}=$ Pinus zone $\quad \mathrm{A}=$ Ancylus Lake

Several $90 \mathrm{~cm}$ long sample series close to each other were taken with a piston sampler from each basin for microfossil and radiocarbon analysis. The lithostratigraphic horizons were observed in the field and later adjusted by means of loss on ignition determined in the laboratory.
The pollen preparates were made, depending on the type of sediment, by either the $\mathrm{KOH}$ or the HF method (e.g. Faegri and Iversen 1975). From each preparate, 200 arboreal pollens were counted for the pollen diagrams. The lowermost clay in the sample series contains less pollen, some of which was redeposited. 
TABLE 2. Radiocarbon dates (non-corrected).

\begin{tabular}{|c|c|c|c|}
\hline BASIN & $L A B . N o$ & DATE $(B P)$ & NOTE \\
\hline $\begin{array}{l}\text { Lehmälampi }{ }^{1)} \\
\end{array}$ & $\begin{array}{l}\text { Su- } 885 \\
\text { Su- } 886\end{array}$ & $\begin{array}{l}9710 \pm 150 \\
9060 \pm 160\end{array}$ & $\begin{array}{l}\text { beginning of transgression } \\
\text { end of transgression }\end{array}$ \\
\hline $\begin{array}{l}\text { Keihilampi }{ }^{2)} \\
\end{array}$ & $\begin{array}{l}\text { Su-1001 } \\
\text { Su-1002 }\end{array}$ & $\begin{array}{l}9720 \pm 140 \\
9080 \pm 180\end{array}$ & $\begin{array}{l}\text { beginning of transgression } \\
\text { end of transgression }\end{array}$ \\
\hline $\begin{array}{l}\text { Lakiassuo } \\
\quad ”\end{array}$ & $\begin{array}{l}\text { Su-1003 } \\
\text { Su-1004 }\end{array}$ & $\begin{array}{l}9080 \pm 90 \\
8780 \pm 110\end{array}$ & $\begin{array}{l}\text { beginning of transgression } \\
\text { end of transgression }\end{array}$ \\
\hline $\begin{array}{r}\text { Luuk } \\
\text { ” }\end{array}$ & $\begin{array}{l}\text { Su-1071 } \\
\text { Su-1072 } \\
\text { Su-1073 }\end{array}$ & $\begin{array}{l}9300 \pm 100 \\
9430 \pm 100 \\
9640 \pm 140\end{array}$ & $\begin{array}{l}\text { end of transgression } \\
\text { beginning of transgression } \\
\text { isolation }\end{array}$ \\
\hline Lull-lampi & $\begin{array}{l}\text { Su-1074 } \\
\text { Su-1075 }\end{array}$ & $\begin{array}{l}8630 \pm 90 \\
8840 \pm 170\end{array}$ & $\begin{array}{l}\text { end of transgression (?) } \\
+ \text { rise of Alnus } \\
\text { beginning of transgression (?) }\end{array}$ \\
\hline $\begin{array}{l}\text { Kaliton } \\
,\end{array}$ & $\begin{array}{l}\text { Su-1076 } \\
\text { Su-1077 }\end{array}$ & $\begin{array}{l}9410 \pm 100 \\
9310 \pm 170\end{array}$ & $\begin{array}{l}\text { beginning of transgression } \\
\text { end of transgression }\end{array}$ \\
\hline $\begin{array}{l}\text { Kakarlampi } \\
\quad ”\end{array}$ & $\begin{array}{l}\text { Su-1100 } \\
\text { Su-1101 }\end{array}$ & $\begin{array}{l}9450 \pm 100 \\
9640 \pm 180 \\
9430 \pm 180 \\
8630 \pm 150\end{array}$ & $\begin{array}{l}\text { beginning of transgression } \\
\text { upper part of transgression } \\
\text { layer } \\
\text { end of transgression } \\
\text { rise of Alnus }\end{array}$ \\
\hline $\begin{array}{l}\text { Kaksoslammet }{ }^{3)} \\
\quad, \\
,\end{array}$ & $\begin{array}{l}\text { Su-1108 } \\
\text { Su-1109 } \\
\text { Su-1110 }\end{array}$ & $\begin{array}{l}9450 \pm 110 \\
9510 \pm 110 \\
9260 \pm 100\end{array}$ & $\begin{array}{l}\text { beginning of transgression } \\
\text { transgression layer } \\
\text { end of transgression }\end{array}$ \\
\hline
\end{tabular}

1) Glückert and Ristaniemi 1980

2) Glückert and Ristaniemi 1982

3) Ristaniemi 1984

Similar observations have been made by Donner and Gardemeister (1971).

The transgression sediment may also contain redeposited pollens, and therefore the relations in the pollen spectra are often mixed. (e.g. Saarnisto 1970, pp. 36-45). In the present case, the pollens of pine are often over-represented, as can be seen by comparing the diagram with some earlier pollen diagrams for the same area (Glückert 1970, 1979). To identify the pollens we used the collection of pollen preparates of the Institute of Quaternary Geology, University of Turku, and made a study of the pollen literature (e.g. Erdtman 1947; Hyde and Adams 1958; Erdtman et al. 1961).
The results are presented in pollen diagrams drawn by the computer (DEC 20) of the University of Turku, and divided into pollen zones, if possible. According to earlier studies, the Ancylus Lake stage in southern Finland coincided with the time of the Betula/Pinus $(\mathrm{P}=\mathrm{B} / \mathrm{P})$ and Pinus/Alnus $(\mathrm{A}=\mathrm{P} / \mathrm{A})$ zone boundaries (e.g. Glückert and Ristaniemi 1980, 1982).

The diatom preparates were made from the same samples as the pollen preparates. Some 200-300 diatoms were counted, except from the bottom clay, which was so poor in diatoms that it only yielded 50 to 100 diatoms. The diatom taxonomy used here agrees with the taxonomies of Hustedt (1930), Cleve-Euler (1951- 


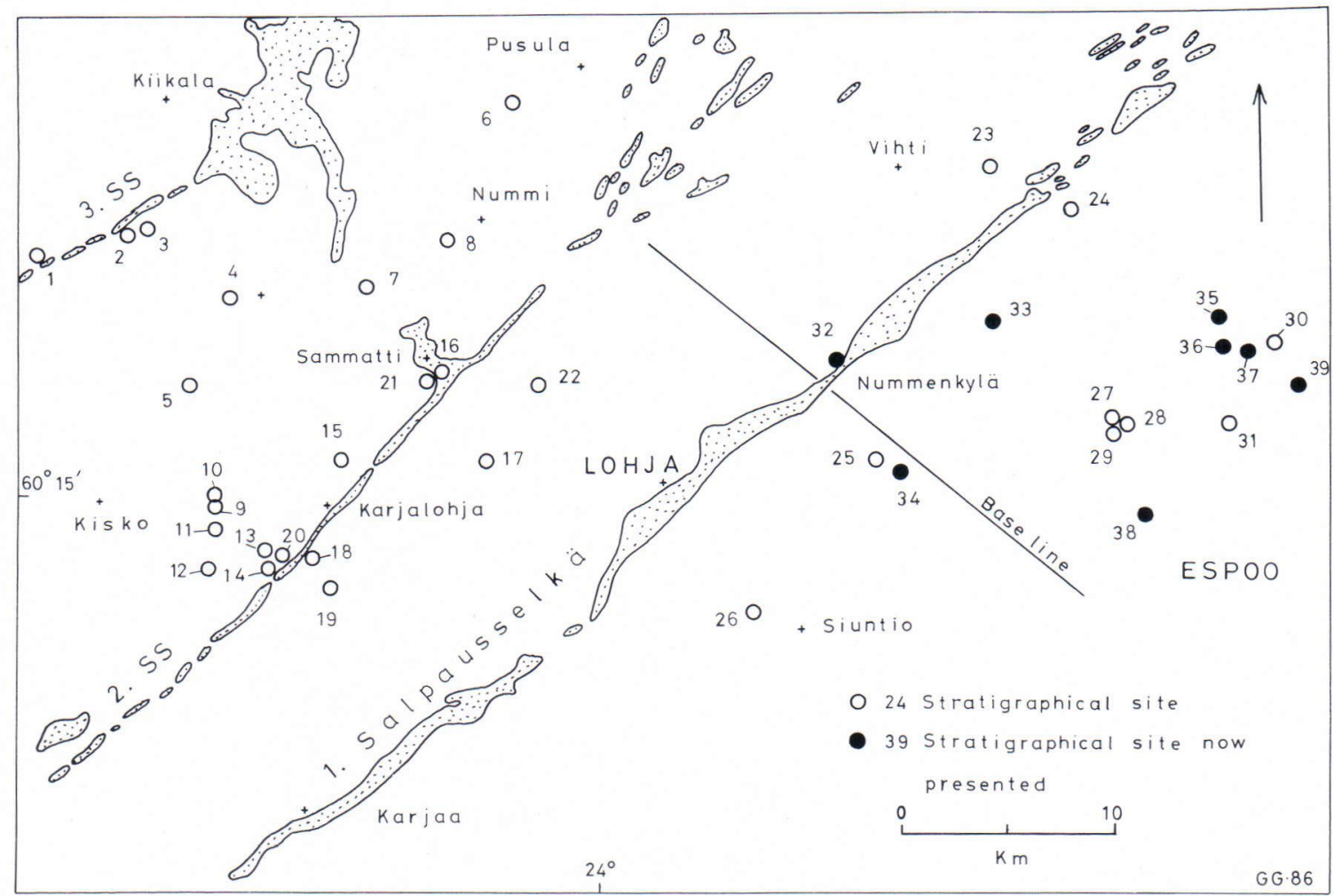

Fig. 2. Study area, with the basins investigated in 1979-1982 (1-39) and the basins discussed in this paper (32-39).

1955), Mölder and Tynni (1967-1973) and Tynni (1975-1981). The diatom preparates were tested and corrected by Risto Tynni of the Geological Survey of Finland. The diatom diagrams were drawn using the same computer that drew the pollen diagrams. Mainly for technical reasons, only $20-40$ species are presented in the diatom diagrams.

The absolute ages of the important lithostratigraphic and biostratigraphic horizons referring to the Ancylus transgression in the area were determined at the radiocarbon laboratory of the Geological Survey of Finland. The ${ }^{14} \mathrm{C}$ dates obtained are given as conventional noncorrected radiocarbon dates BP (T 1/2 $=5568 \pm$ 30 ). For the present study, 28 age determinations were made, 20 of which are listed in Table 2 ; the others have been published earlier (Ristaniemi 1984).
The dated material consists of fine-grained sediments containing organic material, mainly gyttja, clayey gyttja or gyttja clay. The sediments with organic material cause some problems, for example, when the dating results are interpreted (see; e.g., Olsson 1979). The transgression layer in. particular often consists of mixed older minerogenic and organic material from the areas around the basin. However, in the present study the radiocarbon datings were not made from the transgression layer itself but from just beneath and above it.

\section{The basins investigated}

The lithostratigraphy of the eight basins situated in southeastern part of the study area is described in detail with the aid of pollen and 

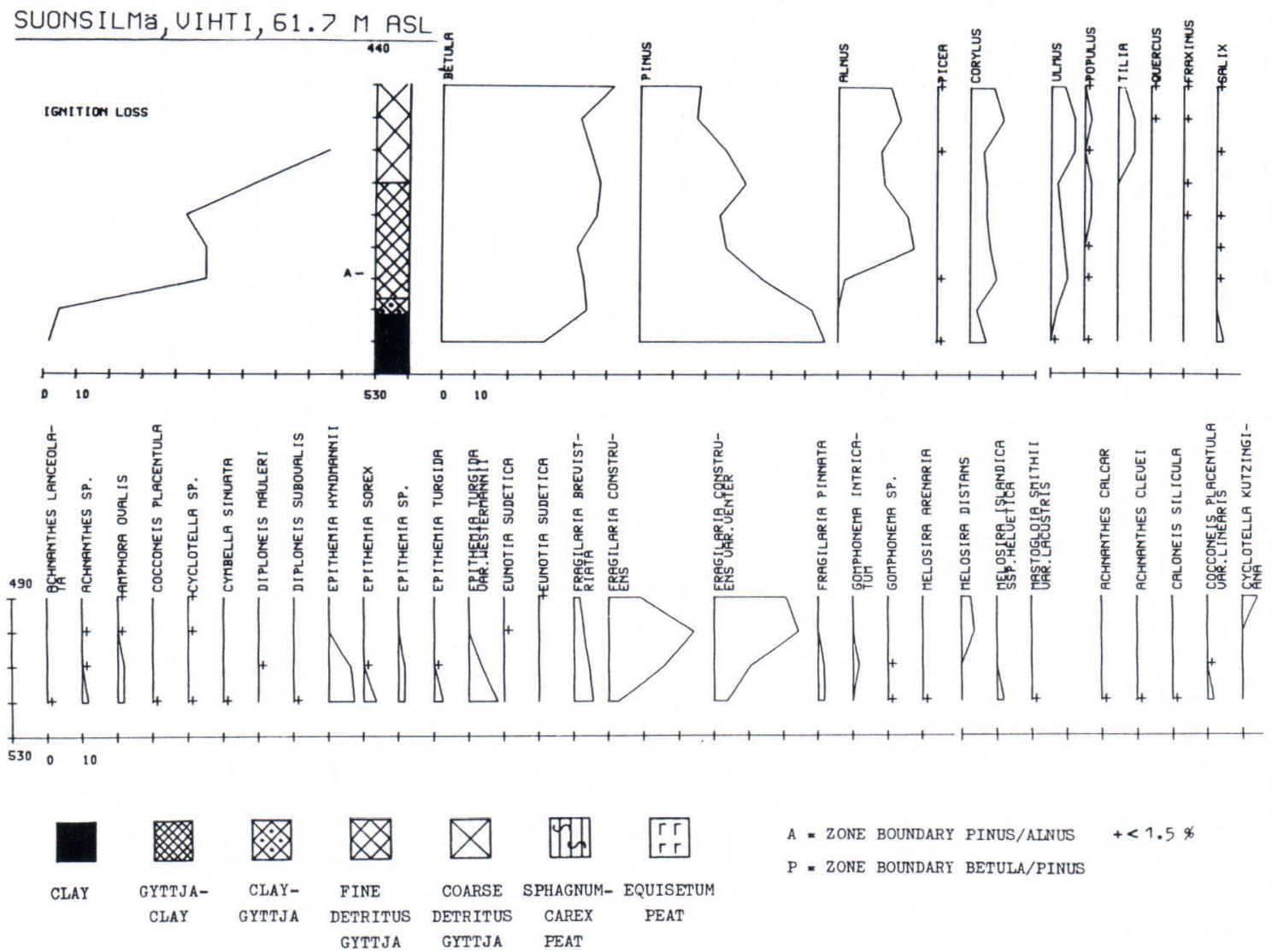

$A=$ ZONE BOUNDARY PINUS/ALNUS $+<1.5 \%$

$P=$ ZONE BOUNDARI BETULA/PINUS

Fig. 3. Pollen and diatom diagrams of Lake Suonsilmä in Vihti. The symbols used in the pollen and diatom diagrams.

diatom analysis, and radiocarbon and loss on ignition determinations. The relations between shore-level displacement and isolation as well as the transgression layer are also discussed (Fig 2.).

\section{Suonsilmä, Vihti}

Basin No. 32, 61.7 m a.s.l., $60^{\circ} 18^{\prime} \mathrm{N}, 24^{\circ} 15^{\prime} \mathrm{E}$.

Pollen and diatom analyses show that the basin of Suonsilmä was isolated from the Ancylus Lake during the Pinus zone. The isolation limit in the sediment lies at a depth of $510 \mathrm{~cm}$, where the clay passes into clayey gyttja. Zone boundary $\mathrm{A}$ lies at a depth of $500 \mathrm{~cm}$. The clay at the bottom of the sample series contains diatoms commonly found in the Ancylus sediments, e.g., Amphora ovalis, Epithemia hyndmannii, E. turgida v.westermannii and Melosira islandica ssp. helvetica; these species are exhausted at a depth of $510 \mathrm{~cm}$. At the same time many Fragilaria species appear that continue to increase after the isolation of the basin from the Baltic (Fig. 3).

Radiocarbon dating of the isolation contact was not succesful because of the paucity of sample material. The horizon of isolation can be studied indirectly with the aid of the rise in the pollen curve of Alnus and the shore-level displacement in this area; the increase in Alnus in the pollen diagram dates back to $8600-8000$ BP (see Glückert 1970; Donner 1971 and Don- 


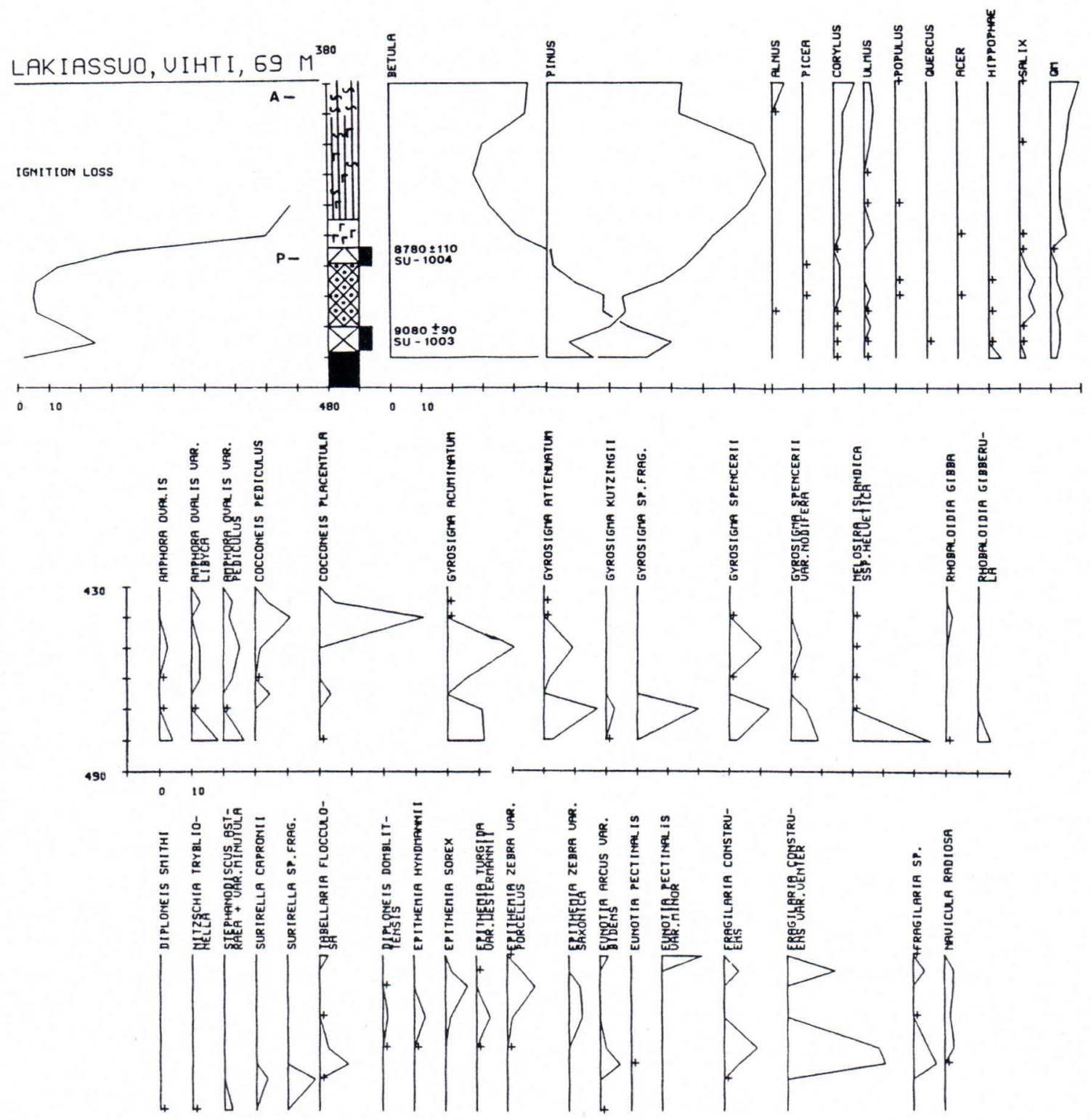

Fig. 4. Pollen and diatom diagrams of the Lakiassuo bog in Vihti.

ner et al. 1978). The isolation occurred before the appearance of Alnus, which means that the basin was cut off at least before 8000 BP. According to the shore displacement curve of Ristaniemi (1984, Fig. 25), the basin of Suonsilmä was already isolated from the Baltic at about 9000 BP (Fig. 3).
Lakiassuo, Vihti

Basin No. 33, 69 m a.s.l., 60'20'N, 2424'E.

A clear transgression layer in the form of a clayey gyttja between two layers of coarse detritus gyttja was observed in the lithostratigraphy of the Lakiassuo basin (Fig. 4). The transgres- 
sion was distinguished visually, by loss on ignition, and in the diatom stratigraphy. The loss on ignition curve shows the same tendency as the lithostratigraphy. In the coarse detritus gyttja beneath the transgression layer the loss on ignition rises to $25 \%$ but in the clayey gyttja (transgression layer) it sinks to $6 \%$. The sharp rise in the loss on ignition curve at a depth of $410 \mathrm{~cm}$ is the result of the final isolation of the basin from the Ancylus Lake (Fig. 4).

Pollen analytical zone boundaries $\mathrm{P}$ and $\mathrm{A}$ are clear (Fig. 4). The transgression layer was deposited during the Betula zone. The end of the transgression was dated to $8780 \pm 110 \mathrm{BP}$ (Su-1004), which is the same date as that ob: tained for zone boundary P. This date is not inconsistent with the results of earlier determinations (e.g. Donner et al. 1978; Glückert 1979), which show a fairly broad dispersion of ages for P. According to the pollen analysis, the date assigned to the beginning of transgression, $9080 \pm$ 90 BP (Su-1003), is obviously too young. The horizon of determination is in the middle of the Betula zone, and, as shown in earlier investigations, the age could be about 9500 years. In another case, the transgression reached the basin just before the transgression maximum, at about 9200 BP, because the threshold of the Lakiassuo basin is at $67 \mathrm{~m}$ and the Ancylus limit in this area at $69 \mathrm{~m}$ a.s.l.

The clay at the bottom of the sample series was deposited during the Yoldia stage, as indicated by the brackish water diatom species: $D i$ ploneis smithii, Nitzschia tryblionella, and Rhopalodia gibberula. The bottom clay also contains several diatoms common in a big lake, such as Gyrosigma acuminatum, G. attenuatum, G. spencerii, and G.s. v.nodifera, Amphora ovalis, A.o.v. libyca, A.o.v. pediculus and Melosira islandica ssp.helvetica. The Yoldia facies, which is made up of ecologically diverse diatoms comprising species typical of big lakes and of brackish and salt water, has been discussed by many authors, for example, Alhonen (1971), Eronen (1974) and Glückert $(1976,1979)$ in Fin- land, and Florin (1977) and Persson (1979) in Sweden. The reason for the mixed diatom content could be the redeposition of older diatoms and fresh water in the coastal areas of Finland during the Yoldia stage.

The diatom analysis indicates that before the transgression reached it, the basin was briefly independent and small in size with coarse detritus gyttja as lake sediment. This sediment contains diatoms typical of small basins, e.g., Fragilaria sp. and Tabellaria flocculosa (Fig. 4). In addition to bottom clay species the transgressive clay gyttja contains others, such as Epithemia hyndmannii and E.turgida $v$. westermannii, which are similar to the diatoms typical of the Ancylus Lake in southern Finland (see Tynni 1966; Glückert 1970; Eronen 1976; Glückert and Ristaniemi 1980, 1982; Eronen and Haila 1982; Ristaniemi 1984) (Fig. 4).

The final isolation of the Lakiassuo basin is clearly visible at a depth of $440 \mathrm{~cm}$, where the species found in the Ancylus sediments disappear, and those of a small lake, e.g., Fragilaria sp. become more numerous. Maximum amounts of Cocconeis pediculus and C. placentula are found at the bottom and top of the transgression layer. The same species also appear in the transgression sediment of the Luuk basin. It is because Cocconeis pediculus is one of the most typical diatom species that Sauramo (1953, pp. 14-15) called this stage of the Baltic the Echineis Sea, earlier the Rhabdonema Sea. He also used the name Echineis transgression for the true transgression of the Kaliton basin (see Kaliton basin in this paper).

\section{Myllyjärvet, Siuntio}

Basin No. 34, 61.7. $m$ a.s.l., 60'16'N, $24^{\circ} 19^{\prime} E$.

The change in lithostratigraphy from bottom clay to clayey gyttja and fine detritus gyttja is clear in the Myllyjärvet basin. The curve of loss on ignition first rises gradually and then steeply where the clayey gyttja passes into fine detritus 

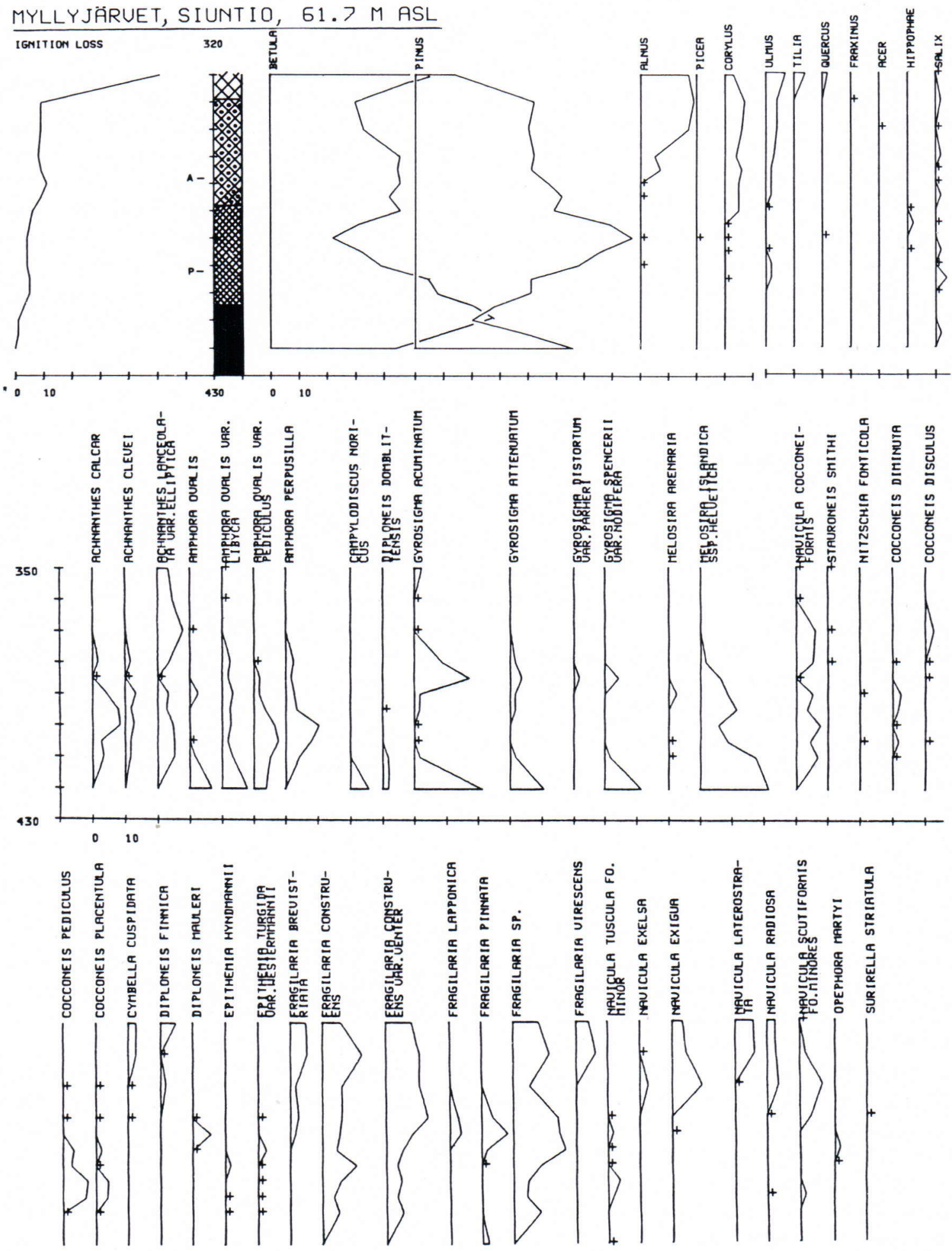

Fig. 5. Pollen and diatom diagrams of Lake Myllyjärvet in Siuntio. 
gyttja. Pollen zone boundaries $\mathrm{P}$ and $\mathrm{A}$ are indicated clearly in the diagram (Fig. 5).

Two distinct changes are seen in the diatom stratigraphy: the first is at a depth of $410 \mathrm{~cm}$, where the species of Melosira islandica ssp.helvetica, Gyrosigma acuminatum, G. spencerii v. nodifera, Campylodiscus noricus, Amphora ovalis and A.o.v.pediculus dicrease or disappear. At the same time, the following species in particular become abundant: Fragilaria sp, Achnanthes sp, Amphora perpusilla and Navicula cocconeiformis (Fig. 5).

The diatoms that disappeared at a depth of $410 \mathrm{~cm}$ reappear at $390-380 \mathrm{~cm}$. Fragilaria pinnata, F. lapponica and Diploneis mauleri also appear sporadically. At $380 \mathrm{~cm}$, the following species also increase: Navicula exiqua, N.radiosa, N.scutiformis v. minores and also Fragilaria brevistriata (Fig. 5).

The second distinct horizon of change in diatom stratigraphy, at a depth of $390-380 \mathrm{~cm}$, is not visible in the lithostratigraphy or loss on ignition. Most of the species that reappear at this depth are typical of the Ancylus sediments. A similar change has been described by Mölder (1955) from the lake Siikajärvi in Espoo, and by Ristaniemi (1984) for the zone of the Second Salpausselkä in the area of Karjalohja - Kisko. There are several examples of the Ancylus transgression in the Helsinki area (Eronen and Haila 1982), where the change mentioned above can be observed in the diatom stratigraphy and loss on ignition but not in the lithostratigraphy.

These changes in diatom stratigraphy can be explained as follows: the water level of the Baltic sank almost to, but not lower than, the level of the threshold of the basin during the Yoldia regression. The influence of the Ancylus transgression can be seen at a depth of 390-380 $\mathrm{cm}$. According to the pollen analysis this horizon of change dates back to the beginning of $\mathrm{Pi}$ nus zone. The final isolation of the Myllyjärvet basin occurred at the middle of the Pinus zone, at a depth of about $370 \mathrm{~cm}$ in the sample series (Fig. 5).

\section{Lull-lampi, Espoo}

Basin No. 35, 59.7 m a.s.l., $60^{\circ} 20^{\prime} \mathrm{N}, 24^{\circ} 39^{\prime} E$.

The lithostratigraphy of the Lull-lampi basin exhibits a clear horizon of gyttja clay in the sample series (Fig. 6); the horizon can also be seen in the curve of loss on ignition. A change of this type at zone boundary $\mathrm{P}$ is understood as a sign of the Ancylus transgression (e.g. Eronen and Haila 1982; Glückert and Ristaniemi 1982).

In this case the problem is not the change in the sediment as a result of the transgression. According to the pollen analysis the end of the "transgression" dates back to the point at which Alnus beeing to appear, dated by ${ }^{14} \mathrm{C}$ determination to $8630 \pm 90 \mathrm{BP}$ (Su-1074). Zone doundary $\mathrm{P}$ cannot be distinguished in the sample series studied. The beginning of the "transgression" layer can be assigned to the Pinus zone with a ${ }^{14} \mathrm{C}$ date of $8840 \pm 170 \mathrm{BP}$ (Su-1075). The pollen and radiocarbon analyses both show that the "transgression" horizon of the Lulllampi basin is clearly younger than the Ancylus transgression in other areas around the First and Second Salpausselkäs (see Glückert and Ristaniemi 1980, 1982). On the other hand, the radiocarbon dates for the Lull-lampi basin are as young as some of those determined for the transgression in the area east of Helsinki (see Donner and Eronen 1981) (Fig. 6).

Neither does the diatom analysis show any signs of a transgression. The isolation contact lies at a depth of $465 \mathrm{~cm}$, at which point the following species indicative of Ancylus sediment disappear: Melosira, islandica ssp. helvetica, Stephanodiscus astraea, S.a.v. minutula, Gyrosigma attenuatum, Achnanthes clevei, Epithemia turgida v. westermannii. At the same depth Melosira italica and Tabellaria fenestrata increase rapidly, demonstrating that sediment was being deposited in a small basin. A marked change in the diatom relations occurs in the "transgression" horizon. The species are typical of a small basin, and there are no diatoms typical of Ancylus sediments (see Glückert and Ristaniemi 1982, p. 104) (Fig. 6). 

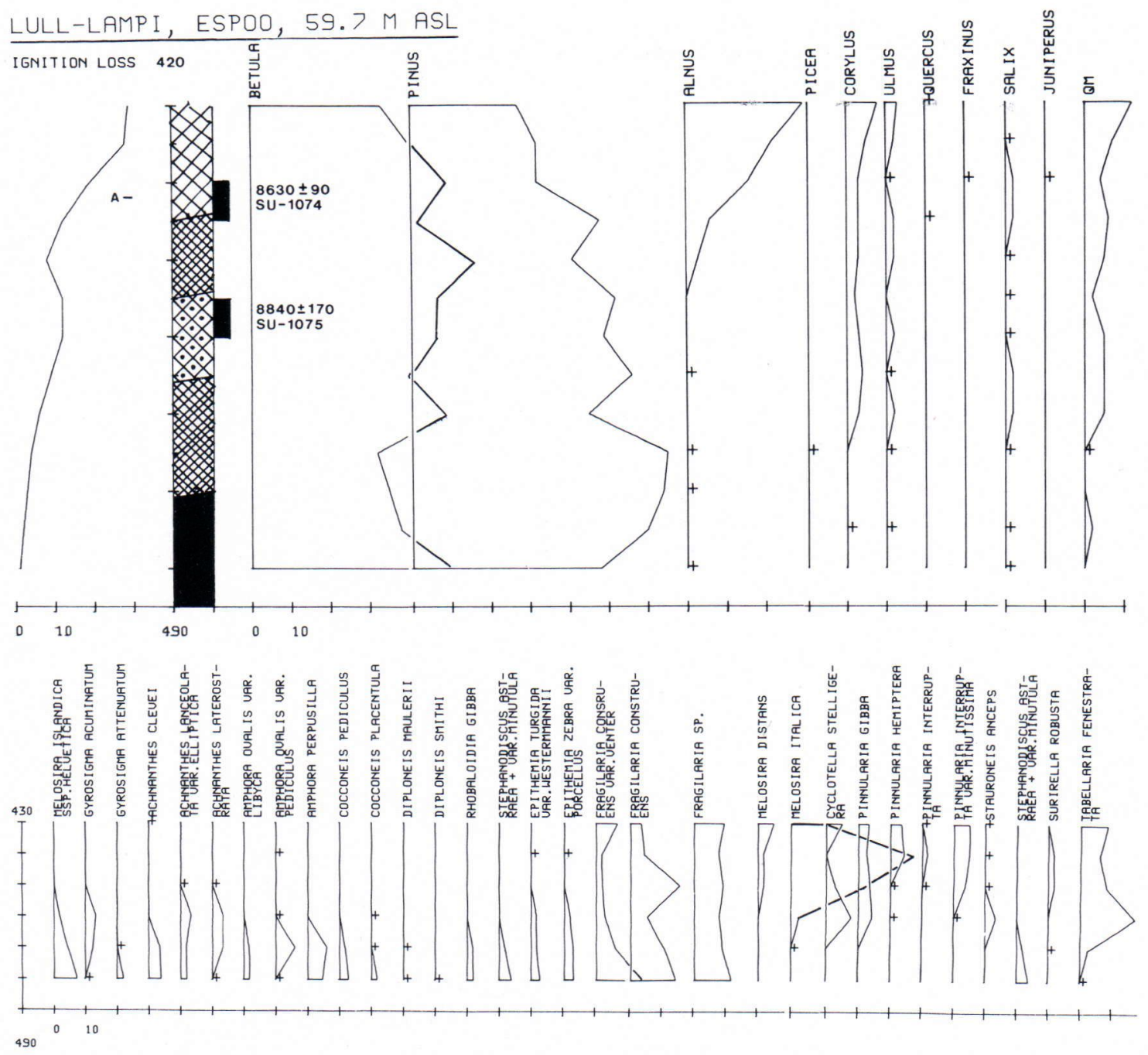

Fig. 6. Pollen and diatom diagrams of the Lull-lampi basin in Espoo.

Kaitlampi, Espoo

Basin No. 36, $68 \mathrm{~m}$ a.s.l., $60^{\circ} 19^{\prime} \mathrm{N}, 24^{\circ} 40^{\prime} \mathrm{E}$.

The bottom clay of the Kaitlampi basin at a depth of 740-720 cm makes this basin of particular interest in the history on the Baltic. It has a brackish water diatom content typical of the Yoldia stage, e.g., Nitzschia navicularis, N. punctata, N. tryblionella v. victoriae, Diploneis smithii and Rhopalodia gibberula, but also abundant Melosira islandica ssp. helvetica and, spo- radically, species such as Stephanodiscus astraea, S.a.v.minutula, Gyrosigma acuminatum, G.attenuatum, Amphora ovalis and A.o.v.libyca. Hence, the species content is ecologically quite varied; those typical of salty water might have been redeposited (see, e.g., Florin 1977; Persson 1979) (Fig. 7).

According to the pollen analysis the Kaitlampi basin was isolated from the Yoldia stage (at a depth of $720 \mathrm{~cm}$ ) during the Betula zone. Pollen stratigraphic zone boundary A is clearly 

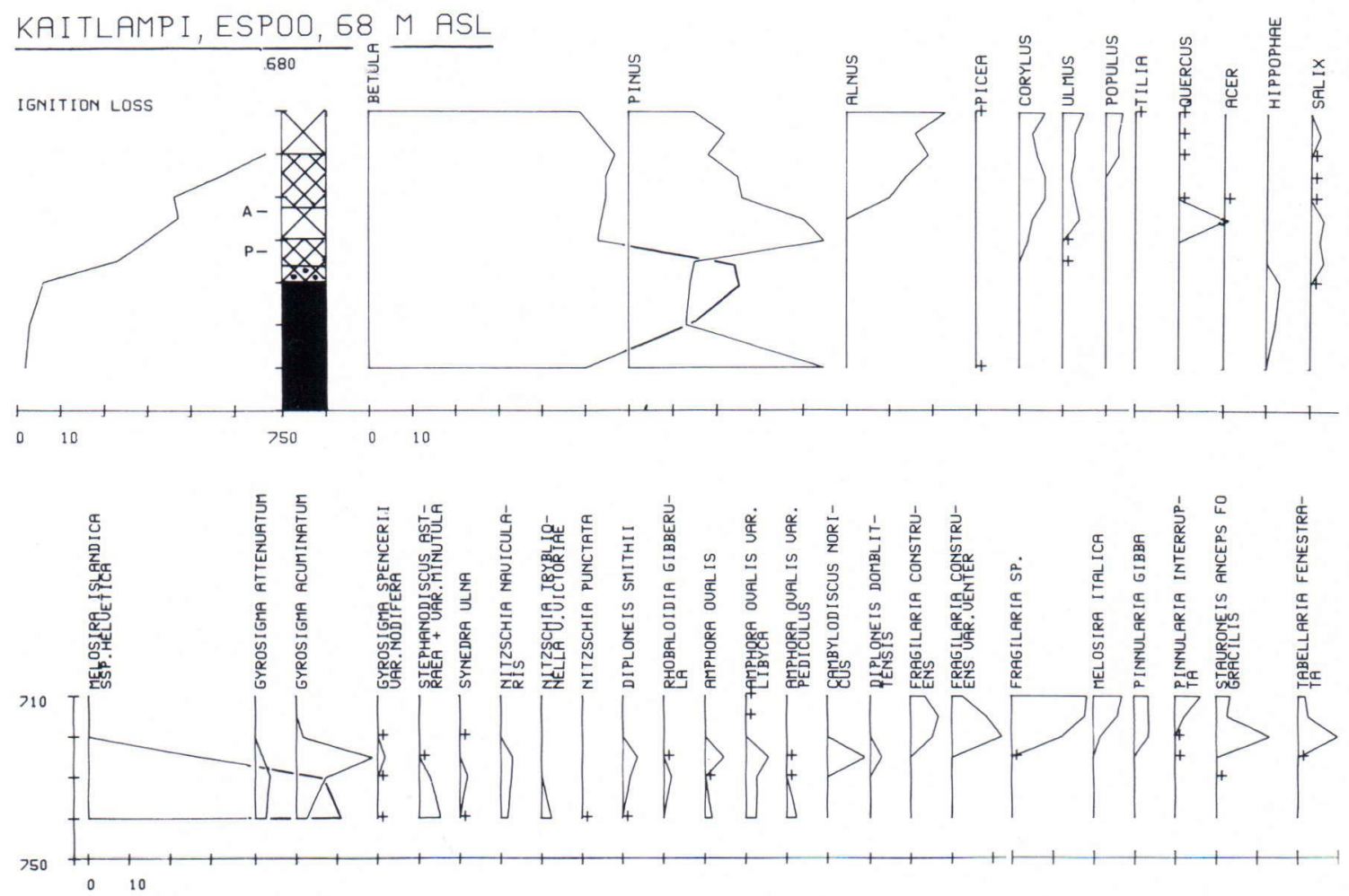

Fig. 7. Pollen and diatom diagrams of the Kaitlampi basin in Espoo.

visible, and the abrupt change in the pollen relations at the zone boundary $\mathrm{P}$ could indicate a hiatus (Fig. 7).

\section{Luuk, Espoo}

Basin No. 37, 63 m a.s.l., $60^{\circ} 19^{\prime} \mathrm{N}, 24^{\circ} 41^{\prime} \mathrm{E}$.

The results of the pollen analysis show that the Luuk basin was first isolated from the Baltic during the Betula zone. The radiocarbon date of the isolation, $9640 \pm 140 \mathrm{BP}$ (Su-1073), is a little older than the beginning of the Ancylus transgression in the basin (Fig. 8). The isolation is also visible in the diatom content. The bottom clay has species referring to the Baltic, e.g., Nitzschia navicularis, Diploneis smithii, Melosira islandica ssp. helvetica, Gyrosigma and Amphora, all diatoms typical of the Yoldia stage in the area. These species disappear above the isolation contact, where the clay passes into clayey gyttja, and, species implying a small lake, e.g., Navicula hustedtii and Fragilaria, become predominant (Fig. 8).

The transgressive clay gyttja horizon dates, as revealed by pollen analysis, back to the latter part of the Betula zone. The coarse detritus gyttja lying beneath the transgression layer has been dated to $9430 \pm 100 \mathrm{BP}$ (Su-1072), and the Equisetum peat above this layer to $9300 \pm 100$ BP (Su-1071) (Fig. 8). The abundance of Fragilaria species decreases in the transgression layer while Cocconeis placentula and C.pediculus increase sporadically (see Glückert and Ristaniemi 1982, p. 104, and Lakiassuo in this paper). Melosira islandica ssp. helvetica also increases sporadically, but Gyrosigma and Amphora species are rare.

The transgression layer in the Luuk basin is conspicuous both visually and by loss on igni- 


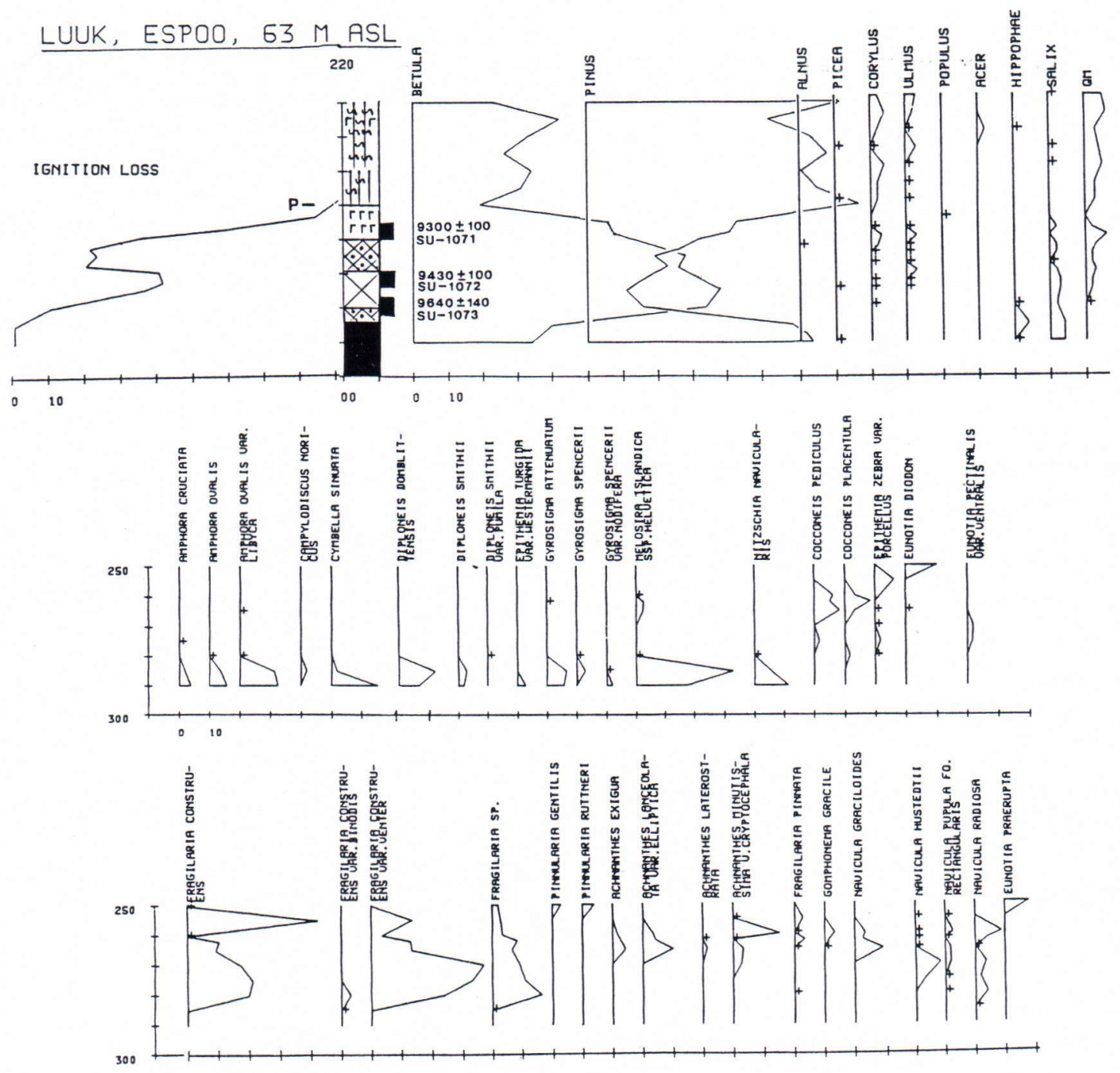

Fig. 8. Pollen and diatom diagrams of the Luuk basin in Espoo.

tion. There is also a distinct change in the diatom stratigraphy but the species are different from those found in the transgression layer described above. Nevertheless, as shown by pollen analysis and radiocarbon dating the transgression layer is the same age as the other Ancylus transgression layers described earlier from southern Finland (see, Glückert and Ristaniemi 1980, 1982; Ristaniemi 1984). Hence we can infer that the transgression layer of the Luuk basin was deposited during the Ancylus transgression of the Baltic. During the transgression a long, narrow bay of the sea reached the basin, and therefore typical Ancylus diatom flora are lacking.

Kakarlampi, Espoo

Basin No. $38,57 m$ a.s.l., $60^{\circ} 14^{\prime} \mathrm{N}, 24^{\circ} 24^{\prime} \mathrm{E}$.

A clear transgression layer consisting of gyttja clay between two clay gyttja horizons was 

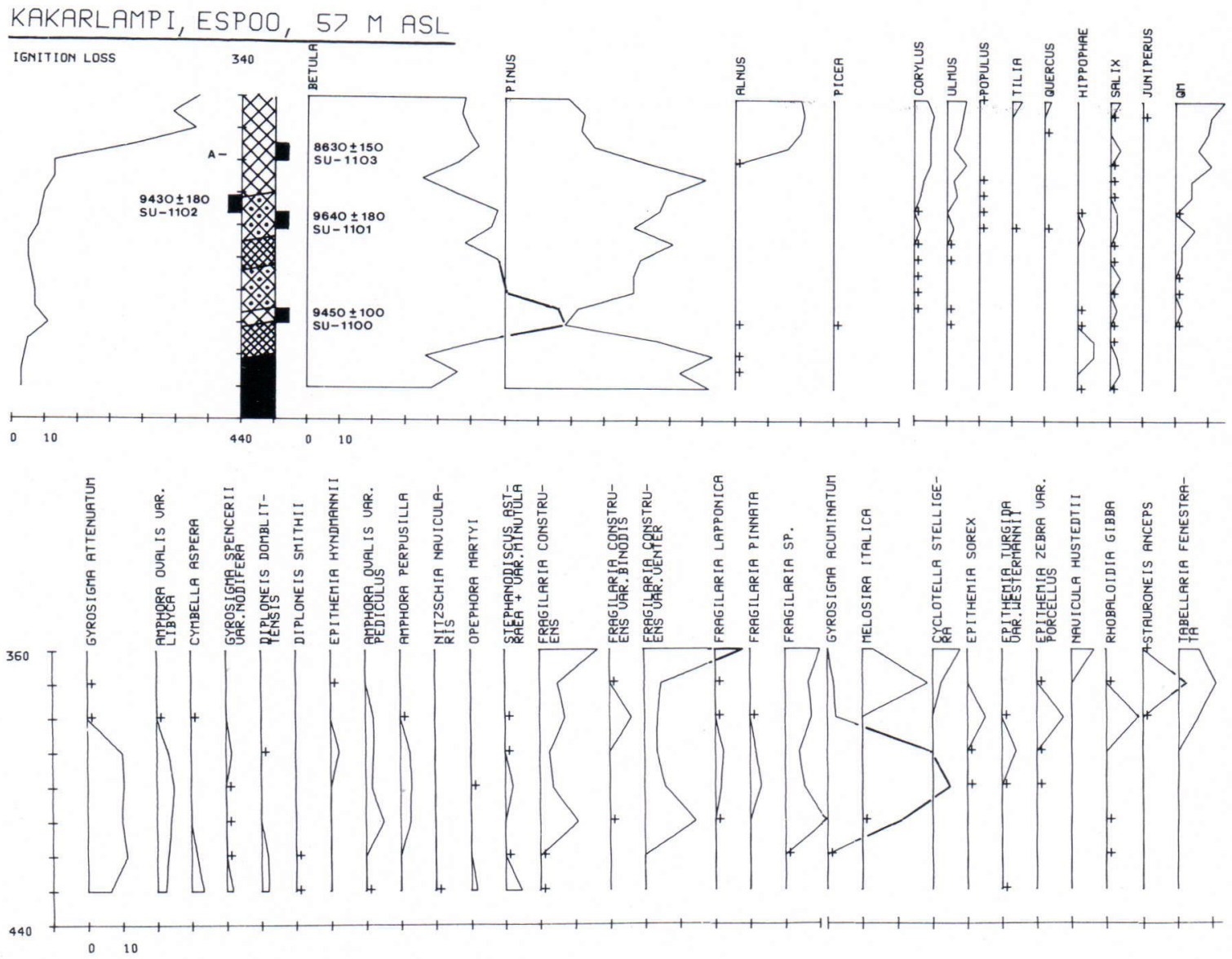

Fig. 9. Pollen and diatom diagrams of the Kakarlampi basin in Espoo.

noted visually in the lithostratigraphy of the Kakarlampi basin (Fig. 9). The gyttja clay at the bottom of the sample series is overlain by a thin layer of fine detritus gyttja beneath the transgression layer, indicating that the water level of the Baltic sank slightly below the threshold of the basin for a short period. This can also be seen in the diatom analysis (Fig. 9).

The results of radiocarbon determinations on the transgression layer are problematic. Zone boundary A is clear and dates back to $8630 \pm$ $150 \mathrm{BP}$ (Su-1103), but it is not clear whether zone boundary $P$ lies at a depth of $400 \mathrm{~cm}$ or 370 $\mathrm{cm}$. Transgression often confuses the pollen relations in the sediment and makes the division of pollen zones difficult. This is seen in the trend of the QM curve in the pollen diagram of the basin. The other three radiocarbon dates are very similar, ie., $9500 \mathrm{BP}$. Obviously the dates for the upper part, $9640 \pm 180 \mathrm{BP}$ (Su-1101), and the end of the transgression, $9430 \pm 180 \mathrm{BP}$ (Su-1102), are too old (Fig. 9).

The bottom clay disclosed only a few diatoms, e.g., Nitzschia navicularis and Diploneis smithii, the most common species of the Yoldia sediments in the area. Besides them, Gyrosigma attenuatum was abundant. The transgression layer, and the thin gyttja layer deposited in a small lake just below it, can be clearly seen in the diatom stratigraphy. Typical diatoms found 
KALITON, ESPOO, 60.2 M ASL

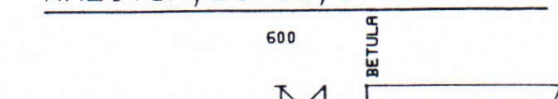

IGNITION LOSS
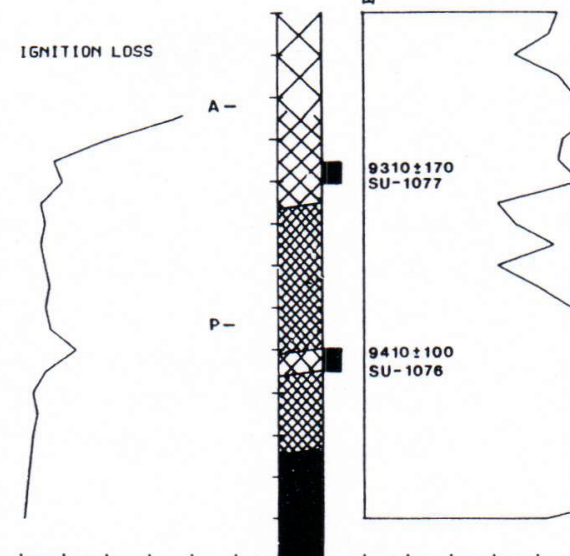

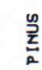

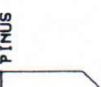

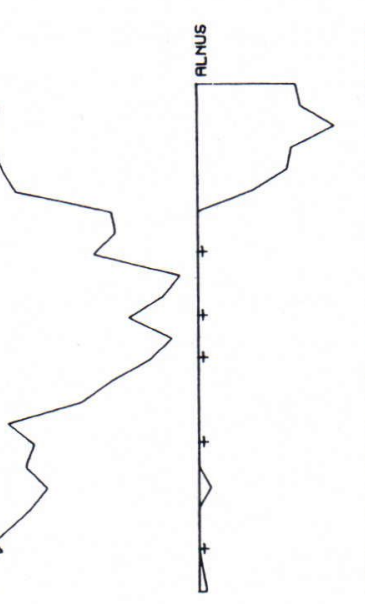

䍃
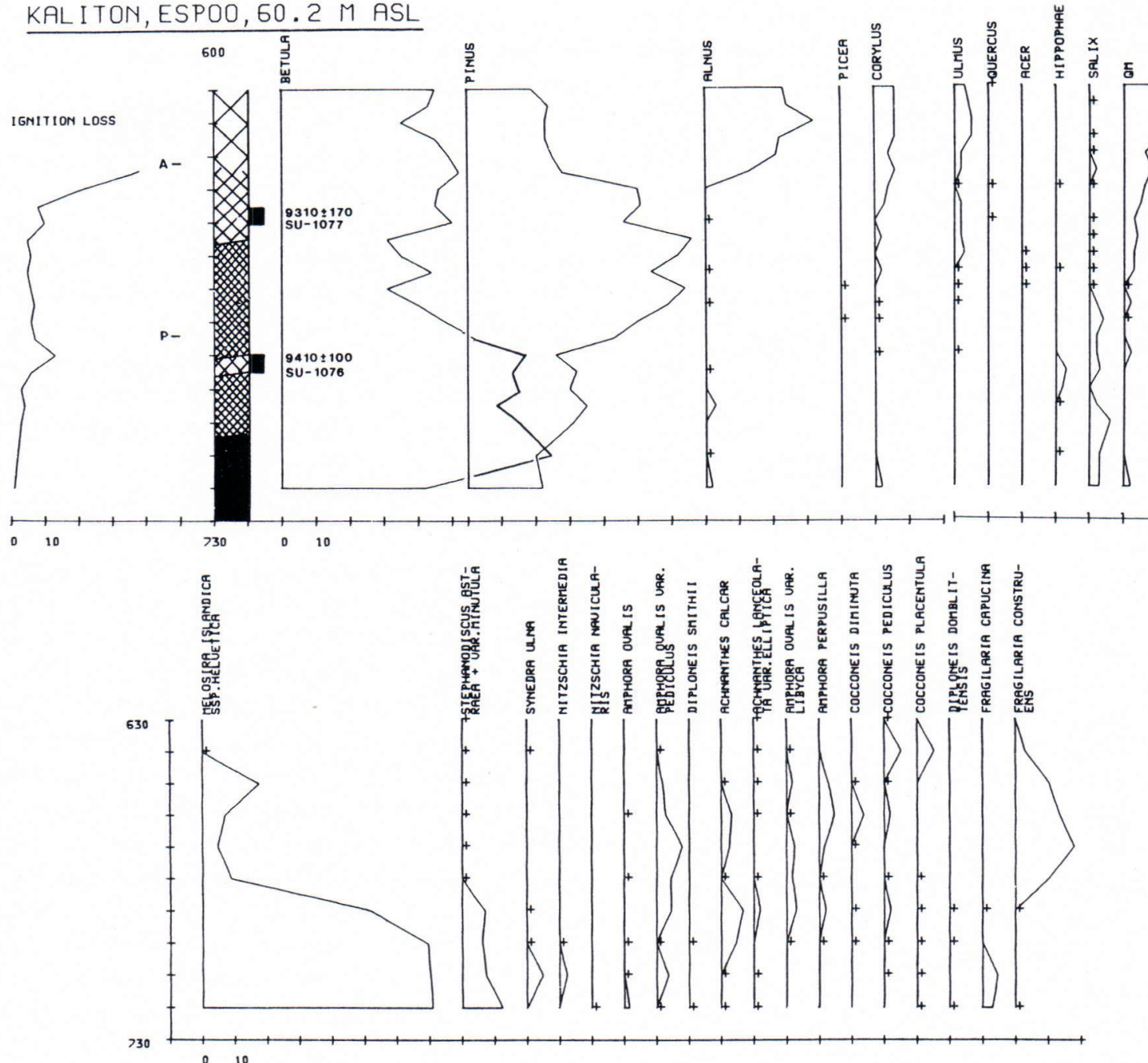

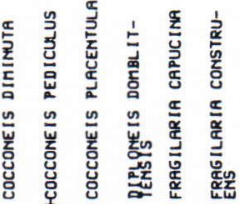
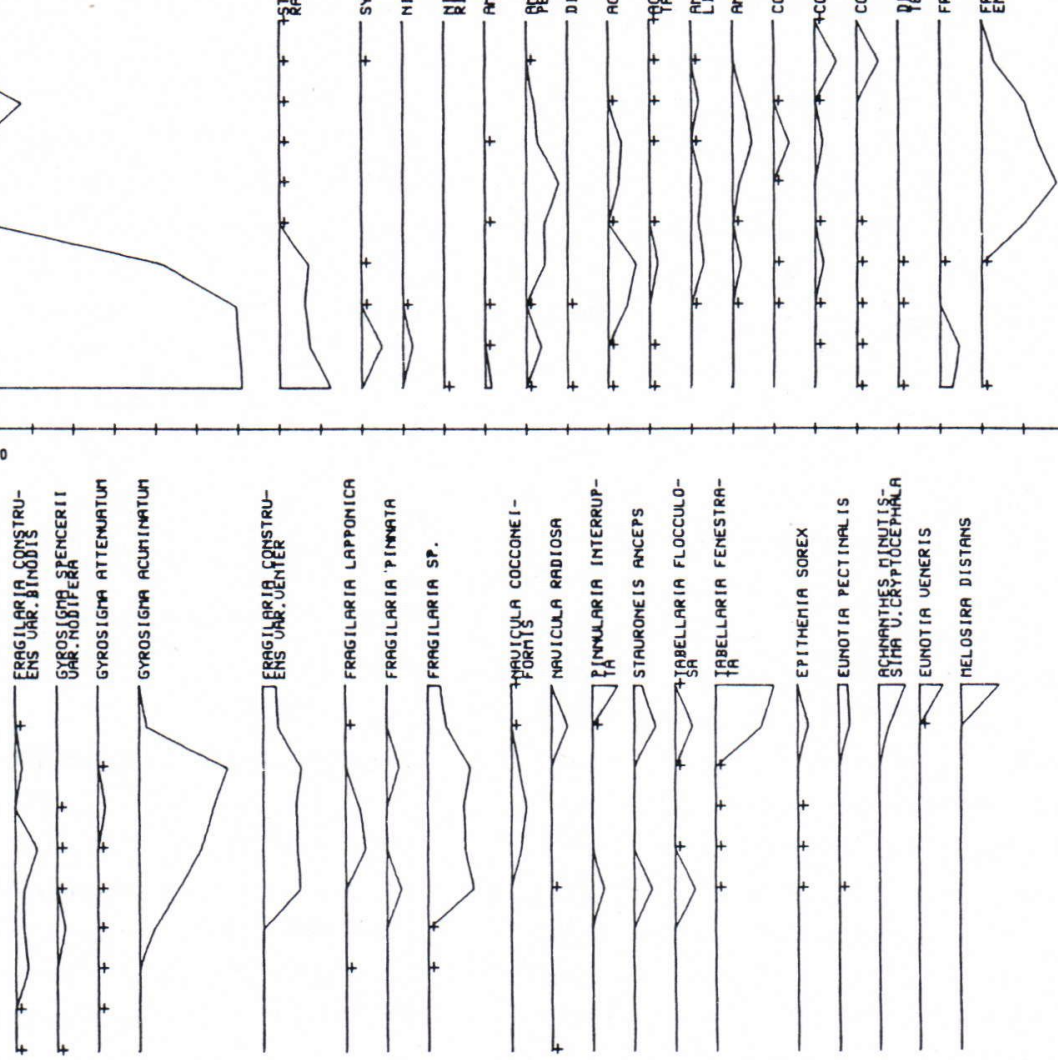

Fig. 10. Pollen and diatom diagrams of the Kaliton basin in Espoo. 
in the trangression layer were Gyrosigma attenuatum, G. acuminatum, Stephanodiscus astraea, S.a.v.minutula, Fragilaria lapponica and F. pinnata. The brief increase in Fragilaria species at $410 \mathrm{~cm}$ indicates that Kakarlampi was an independent basin for a short time before the transgression (Fig. 9).

The lithostratigraphy of the Kakarlampi basin and the pollen and radiocarbon determinations bear witness to the difficulty of drawing a zone boundary when transgression has mixed the sediment. In each case we have a real transgression layer with a diatom content representig the Ancylus transgression layers studied in other parts of southern Finland.

\section{Kaliton, Espoo}

Basin No. 39, 60.2 m a.s.l., $60^{\circ} 18^{\prime} \mathrm{N}, 2^{\circ} 44^{\prime} \mathrm{E}$.

According to the present study, the transgression layer of the Kaliton basin, a clayey gyttja between two fine detritus gyttja layers, can be clearly observed visually, by loss on ignition and by diatom analysis (Fig. 10). Pollen analysis places the beginning of transgression back to the very end of the Betula zone. The fine detritus gyttja, deposited in a small isolated pond and lying beneath the transgression layer, has been dated to $9410 \pm 100 \mathrm{BP}$ (Su-1076). The main part of the transgression and the end of it date back to the Pinus zone (Fig. 10).

Radiocarbon determinations date zone boundary $\mathrm{P}$ in the Kaliton basin to about 9400 BP. The altitude of the threshold of the basin is only one metre below that of the Ancylus limit in this area (Table 1), this transgression was of short duration as can be inferred from the radiocarbon dates (Fig. 10).

The basin of Kaliton was isolated from the Baltic twice, the first time from the Yoldia stage during the Betula zone. The diatoms in the bottom clay, Nitzschia navicularis and Diploneis smithii, refer to the Yoldia stage. At a depth of $685 \mathrm{~cm}$ in the fine detritus gyttja, indicating a small, isolated pond, the abundance of diatoms typical of the Ancylus Lake in the area, e.g., Melosira islandica ssp. helvetica, Stephanodiscus astraea, and S.a.v. minutula decreases rapidly. At the same time Fragilaria species, and also Pinnularia interrupta, Stauroneis anceps and Tabellaria flocculosa increase briefly. Gyrosigma acuminatum, Melosira islandica ssp. helvetica and Fragilaria species predominate in the transgression layer. Both the diatom analysis and the lithostratigraphy indicate that the Kaliton basin was an independent lake for some time before the transgression reached the threshold of the basin (Fig. 10).

The basin of Kaliton has been studied earlier by Sauramo $(1953,1954,1958)$ and Mölder, Valovirta and Virkkala (1957, p. 31). Although Sauramo found some salt water species in this basin, there were no salt water diatoms in the present sample series taken from above the bottom clay. However, the pollen diagram confirms the results presented by Sauramo and Mölder et al. (1957). The dates determined by pollen analysis for the transgression layer agree also with those for the area east of Helsinki (see Tynni 1966; Eronen 1976; Donner and Eronen 1981; Eronen and Haila 1982). Also the relative age for the transgression in the Kaliton basin is the same as that in the Kakarlampi basin and in the Lehmälampi basin at the Second Salpausselkä. However, the pollen analytical date for the transgression is younger than in the Luuk and Lakiassuo basins, and in the Keihilampi and Kaksoslammet basins in the area of the Second Salpausselkä (see Fig. 12).

\section{The age of the Ancylus transgression}

The distance diagram in Fig. 11 shows the eight basins of the study area and the First Salpausselkä at Nummenkylä, near Lohja. The sites of the basins are projected against the base line (see Fig. 2). The base line of the shore diagram $\left(310^{\circ}\right)$ is drawn through the First Salpaus- 
Fig. 11. Lithostratigraphic distance diagram between Espoo and the First Salpausselkä (1. SS).

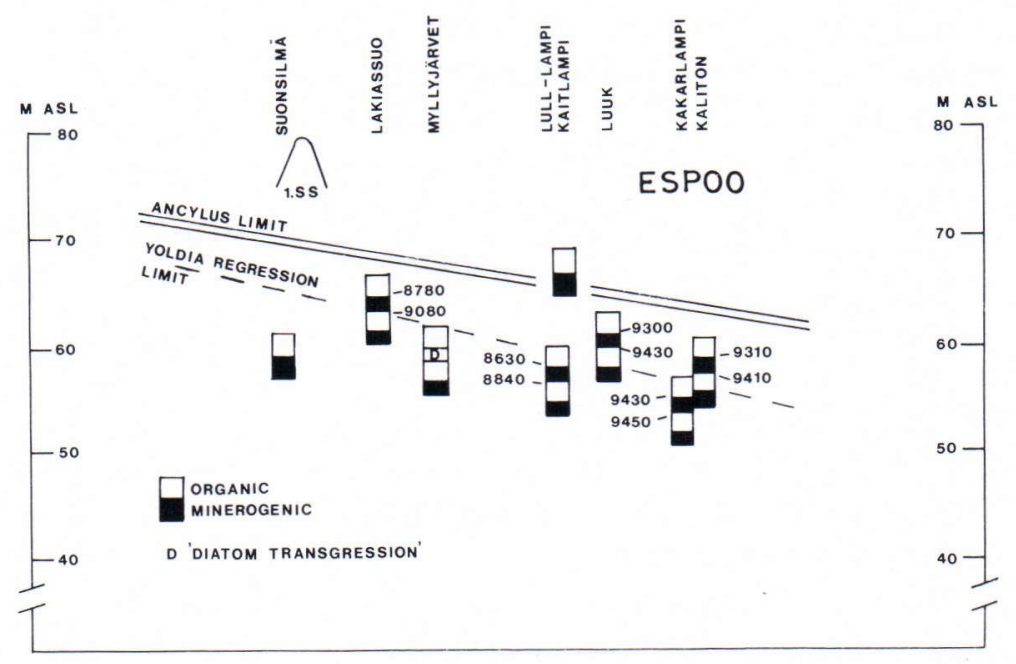

selkä at Nummenkylä and runs towards the centre of uplift in Fennoscandia. The stratigraphy and radiocarbon dates are presented for each basin studied. The level of the Yoldia regression and the Ancylus limit are drawn on the basis on earlier investigations in the area (Glükkert 1970, 1979; Glückert and Ristaniemi 1980, 1982) (Fig. 11).

With the aid of Fig. 11 we are able to estimate the amplitude of the transgression and the position of the basins at different altitudes in the course of the transgression. Detritus gyttja containing diatom species of a small lake were deposited before the transgression layer in the basins of Lakiassuo (No. 33), Luuk (37), Kakarlampi (38) and Kaliton (39). This indicates that the level of the Baltic sank slightly below the thresholds of these basins as a result of the Yoldia regression. Just before the transgression reached their thresholds these basins were briefly isolated lakes (Fig. 11).

The transgression layer of the Lull-lampi ba$\sin (35)$ is obscure and shows quite a young age. No signs of a real transgression were observed in the sediments and loss on ignition of the Myllyjärvet basin (34), although there was a connection between the Baltic and the basin during both the Yoldia stage and the Ancylus transgression. The transgression can be shown only as a diatom transgression (Fig. 11; and Mölder 1955; Ristaniemi 1984). The Kaitlampi basin (36) was finally isolated from the Baltic at the Yoldia stage; the Ancylus transgression never reached the threshold of this basin. On the other hand, the Suonsilmä basin (32) lies at such a low altitude ( $62 \mathrm{~m}$ a.s.l.) that it could not have been isolated from the Baltic before the Ancylus regression (Fig. 11).

In the lithostratigraphy of the Kakarlampi basin (38) the gyttja layer deposited before the transgression layer is quite thin, and the changes in the diatom content of this basin are barely visible, albeit more clearly than those of the Myllyjärvet basin (34). This means that during the Yoldia regression the water level sank only slightly below the threshold of the Kakarlampi basin (38) before the Ancylus transgression reached the basin (Fig. 11).

The amplitude of the Ancylus transgression in the area studied varies in a range of several metres: about 4-5 metres in the area of the First Salpausselkä and about 6-7 metres in the area around Espoo. The duration of the transgression was dated to vary from $9700-9500$ to 9200-9000 BP. These results agree with figures presented earlier for southern Finland (Glük- 
kert and Ristaniemi 1980; 1982; Eronen and Haila 1982; Haila 1983) (Fig. 11).

The amplitude of the transgression increases southeastwards in the direction of more modest uplift. This is what one expect if there were no irregularities in the uplift. However, as pointed out earlier, irregularities in uplift are suggested by the marked dispersion in the dates determined for the transgression by radiocarbon and pollen methods (e.g. Glückert and Ristaniemi 1982; see also Mörner 1979, pp. 251284). Unequivocal evidence in support of this opinion is, however, lacking.

The variation in dates for the Ancylus transgression in southern Finland is due to several factors, e.g. the variation in altitude of the thresholds of the basins, indicating that transgression began at different times in the basins studied. The dispersion of dates for the transgression depends on the metachronous age of pollen zone boundary $\mathrm{P}$ in the basins of the area now studied and also throughout southern Finland.

The pollen analytical zone division of Donner (1971) became established in Finland at the beginning of the 1970s. In this division, the date for pollen zone boundary P in SW Finland is $9000 \mathrm{BP}$ and that for A $8000 \mathrm{BP}$. In this paper, we use the term "old opinion" about this wellestablished pollen chronology.

Fig. 12 presents the duration of the Ancylus transgression in two diagrams on the basis of pollen analytical results (relative ages) and radiocarbon determinations (absolute dates) in all the transgression basins studied between Espoo and the Third Salpausselkä. The radiocarbon and pollen analytical dates are given separately, and one should not draw a parallel between them because they are at different scales.

In general the date $9000 \mathrm{BP}$, which is the mean value of many determinations, has been assigned to $\mathrm{P}$ in southern Finland (e.g. Donner 1971; Donner et al. (1978). However, this date cannot be applied to the whole southern part of the country, and zone boundary $\mathrm{P}$ must be
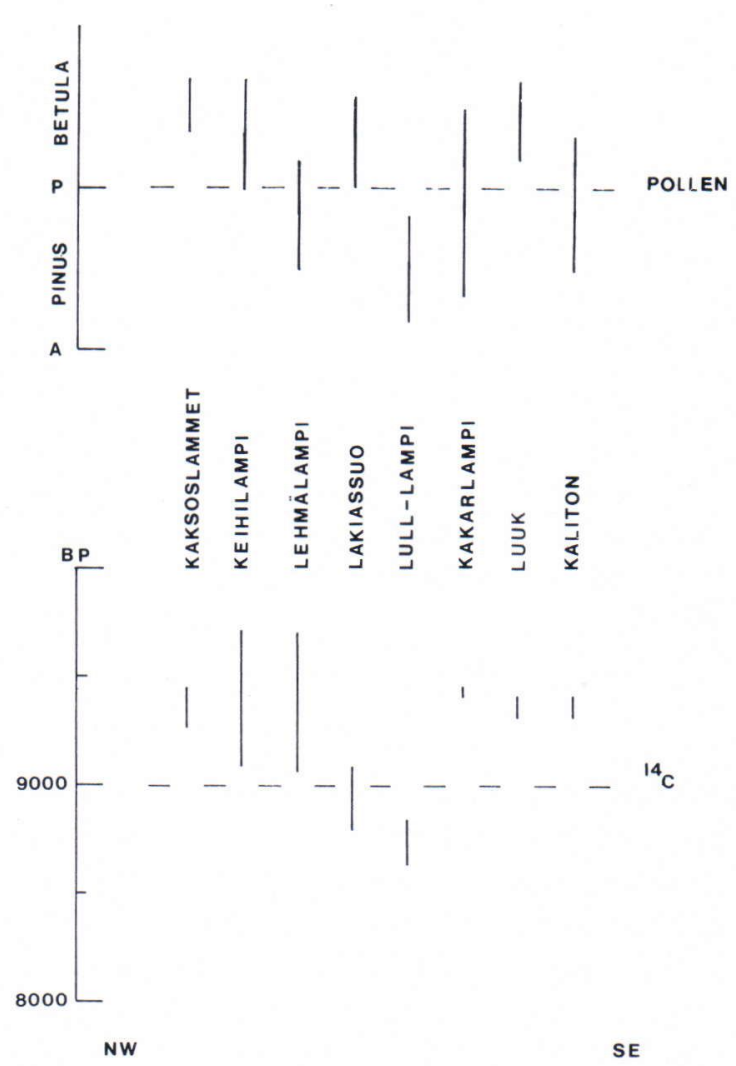

Fig. 12. The duration of the Ancylus transgression based on pollen and radiocarbon determinations for different parts of research areas I and II (see Fig. 1). Note the different scale of the diagrams when comparing the duration of the transgression.

examined separately in each area studied (Ristaniemi 1984). In the present paper we have concluded that this mean value for the age of $\mathrm{P}$ cannot be used just as it is, not even in a small area. Fig. 12 clearly indicates that the age P varies conspicuously within a small area.

For example, the radiocarbon dates of the Keihilampi and Lehmälampi basins and of the Luuk and Kaliton basins are approximately the same, but the pollen analytical dates differ considerably (Fig. 12). In the Luuk and Kaksoslammet basins the results of radiocarbon dating and pollen analysis agree with the "old opinion" held for zone boundary P, ie. $9000 \mathrm{BP}$. 
Fig. 13 Relative shore displacement curves for the area studied drawn according to radiocarbon and pollen dates. Note absolute (left) and relative scale (right).
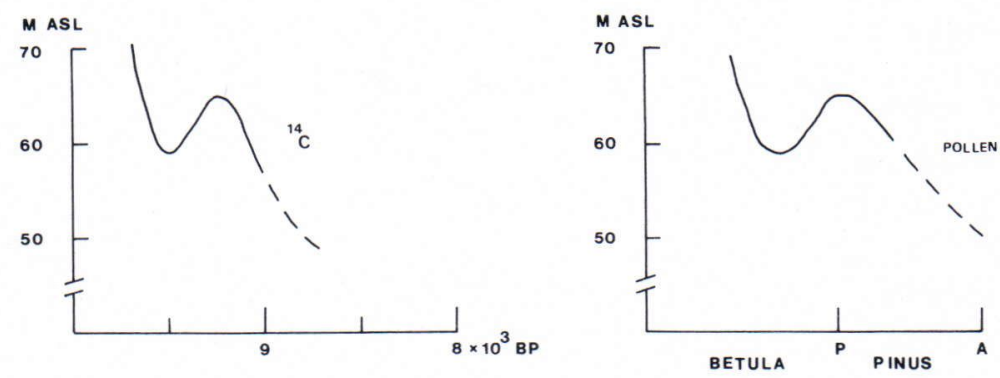

Changes in sedimentation usually indicate changes in water level, causing heavy soil erosion especially during a transgression, e.g. at the altitude of the Ancylus limit. This often causes old organic and minerogenic material to be mixed with the transgression sediment and hence the pollen relations undergo a considerable change.

Fig. 13 shows two relative shore displacement curves for the whole area studied, the ${ }^{14} \mathrm{C}$ curve at an absolute scale and the pollen curve at a relative scale. The ${ }^{14} \mathrm{C}$ curve was drawn on the basis of the dates for the transgression layers from all eight basins dated. The part of the curve after $9000 \mathrm{BP}$ (dashed line) was drawn in accordance with the study of the Salpausselkä area by Ristaniemi (1984). According to the ${ }^{14} \mathrm{C}$ results the Ancylus transgression began at about $9500 \mathrm{BP}$ and reached its maximum at about 9200 BP. Thus the Ancylus regression started at about $9200 \mathrm{BP}$, being rapid at the beginning. These results agree with earlier dates obtained for southern Finland (Eronen 1976; Eronen and Haila 1982; Glückert and Ristaniemi 1982; Ristaniemi 1984) (Fig. 13).

The pollen curve in Fig. 13 was constructed using pollen dates for the same eight basins. The younger part of the curve (dashed line) was drawn on the basis of the pollen analysis of the Salpausselkä area presented by Ristaniemi (1984). According to the pollen dates the Ancylus transgression clearly began during the Betula zone and reached its maximum at zone boundary $\mathrm{P}$. Because of the relative distance in the pollen curve between $\mathrm{P}$ and $\mathrm{A}$ we cannot draw conclusions about the rapidity of the Ancylus regression (Fig. 13).

If we compare the two curves we find ourselves up against the same problem as in Fig. 12. According to the earlier interpretation (the "old opinion"), the radiocarbon date of the transgression maximum should be about 9000 BP if compared with the pollen curve. Further, if we compare the date of the transgression maximum with the ${ }^{14} \mathrm{C}$ curve, the maximum of the pollen curve should clearly be before 9000 BP (Betula zone). According to our results, the date for the Betula/Pinus zone boundary in the study area is about 9300-9200 BP.

The "old opinion" gave different dates for zone boundary B/P, which we attributed to error factors or to faulty dating. However, we did not take into account the fact that also the earlier age, the "old opinion", was dated with the radiocarbon method and could have been erroneous.

Comparison of the pollen relations with an earlier pollen analysis of peat (Glückert 1970, 1979) does not reveal marked differences, except in the Kakarlampi basin (38). This indicates that the amount of redeposited pollen material is not considerable. The Ancylus transgression occurred in this area mainly during the $B e$ tula zone and most of the redeposited pollens consist of Betula.

Only a few diatoms not typical of the Ancylus sediments have been found in the sediments of the Ancylus transgression; redeposition of diatoms also seems to have been quite rare. The diatoms of the transgression sediments 


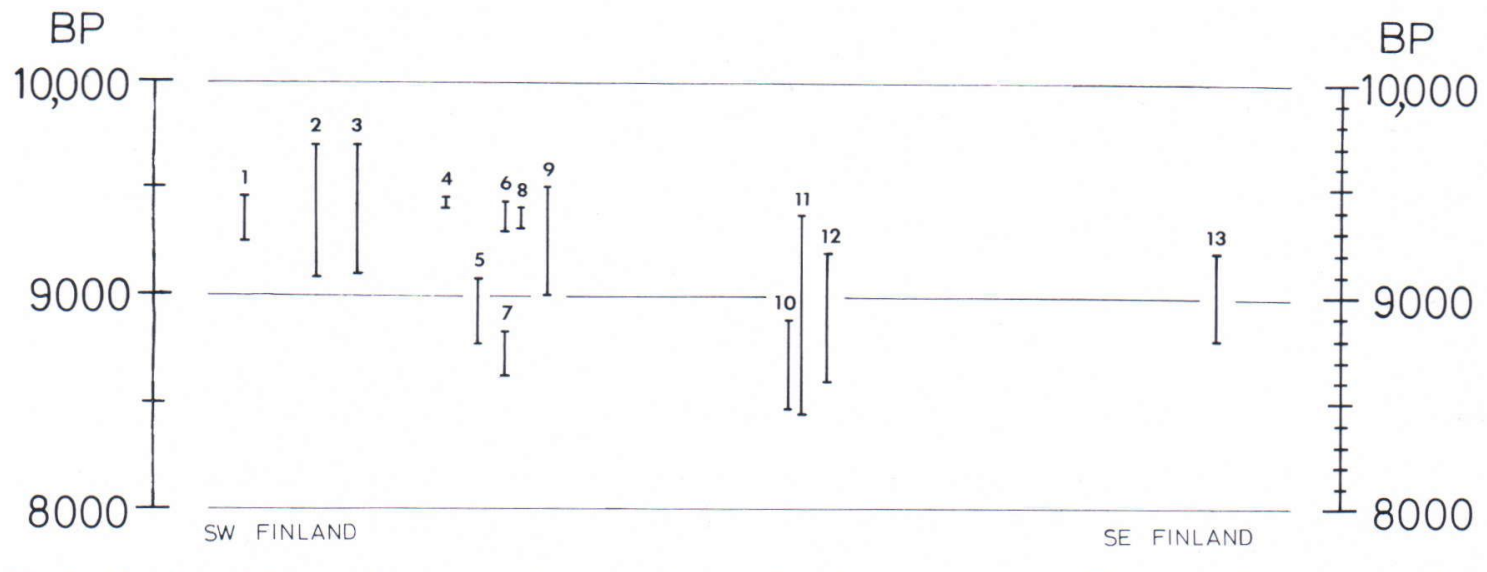

Fig. 14. Duration of the Ancylus transgression according to radiocarbon dates, southern Finland: $1=$ Kaksoslammet (Ristaniemi 1984); 2=Lehmälampi (Glückert and Ristaniemi 1980); 3=Keihilampi (Glückert and Ristaniemi 1982); 4=Kakarlampi; $5=$ Lakiassuo; $6=$ Luuk; $7=$ Lull-lampi; $8=$ Kaliton; 9=Helsinki area (Eronen and Haila 1982, shore displacement curve); 10=Kopinkallionsuo (Donner and Eronen 1981); 11=Huiskaissuo (Donner and Eronen 1981); 12=Haapasuo (Tynni 1966); and 13=Hangassuo (Eronen 1976).

include several species that have also been found in sediments deposited during the Yoldia stage. Species indicating brackish water, such as Diploneis smithii and Nitzschia navicularis, found in Yoldia sediments have not been found in the sediments of the Ancylus transgression within the area studied.

\section{The Ancylus transgression in the Baltic sphere}

Sauramo $(1953,1954)$ reports two transgression layers in the lithostratigraphy of the Kaliton basin. The sedimentation of the lower layer began during the last part of pollen zone IV and ended during zone $\mathrm{V}$ a. Most of the diatom species of the bottom clay and the lower transgression layer are the same as in the area now studied between Espoo and the First Salpausselkä. Sauramo (1953, p. 15) also found species indicating slightly salty conditions, such as Campylodiscus echeneis, in this transgression layer. He connects this "Echineis transgression" with the beginning of the great climatic optimum, whereas the upper transgression layer corre- sponds to the true Ancylus transgression and took place later, during pollen zone $\mathrm{V} \mathrm{c}$.

According to Mölder et al. (1957, p. 10-14) there are signs of only one boreal $(\mathrm{V})$ transgression - the Ancylus transgression - in the same Kaliton basin. The diatom analysis does not suggest salty water. The diatom species are the same as in the material described in the present paper.

Tynni (1966, p. 49) has studied the Ancylus transgression horizon of the Haapasuo basin in Askola, and obtained a date of about 9200 BP for the sediment just beneath the transgression layer, and about 8600 BP for the sediment above it. In his pollen diagrams, which contain the Ancylus transgression, the beginning of the transgression is clearly visible during the Betula pollen zone and the end during the Pinus pollen zone (Tynni 1966, pp. 49-58) (Fig. 14).

In the Hangassuo basin, Sippola, SE Finland, the beginning of the transgression has been dated by pollen analysis back to the $B e$ tula/Pinus zone boundary and the end to the $P i$ nus zone (Salmi 1948; Eronen 1976). The radiocarbon dates for the correspondig horizons are about $9200 \mathrm{BP}$ and $8800 \mathrm{BP}$ (Eronen 
1976, pp. 68-71). Both of the dating methods indicate that the Ancylus transgression began and ended later in the Hangassuo basin than in the area of Espoo - First Salpausselkä (Fig. 14). Material recently analysed from the area east of Helsinki indicates that the Ancylus transgression is younger in this area, too (Donner and Eronen 1981), ie. about 9500-9000 BP (Eronen and Haila 1982, p. 122).

The differences between the radiocarbon dates from different areas are, however, quite small and mostly within the limits of error of the method. The dates for the pollen zones in SW and SE Finland also differ from each other. The discrepancies in the pollen and radiocarbon dates could also be due to differences in uplift in different parts of southern Finland (Glückert and Ristaniemi 1982). For example, uplift has been greater in SW Finland than east of Helsinki. Thus, the Ancylus transgression should have begun earlier in the area of smaller uplift, because of sychronous changes in water level. This is not what happened, however, and in fact the transgression began earlier in the area greater uplift (SW Finland) than in the area of smaller uplift (SE Finland). The magnitude of the age differences suggests that there were probably irregularities in the uplift. At the beginning of the Ancylus transgression, about $9600 \mathrm{BP}$, the margin of the Scandinavian Ice Sheet had just retreated from the Central Finland ice marginal formation. Thus this ice probably delayed in southern Finland.

Elsewhere within the Baltic sphere the Ancylus transgression has been dated to the Yoldia stage, that is, it is older than in the area east of Helsinki. For example, in the Blekinge area, southern Sweden, the Ancylus transgression has been dated to 7600-7000 BC (Berglund 1965, p. 36). According to Nilsson (1968, Fig. 32 ), the Ancylus transgression began in the Karlskrona area at about $7500 \mathrm{BC}$ and ended at about 6500 BC. In Estonia the Yoldia I transgression has been dated to 9700-9500 BP (Kessel and Raukas 1979). Gudelis (1979, Fig. 9) dates the beginning of the Ancylus transgression to $9200 \mathrm{BP}$ and the end to about $8500 \mathrm{BP}$.

From his shore observations Synge (1981) has established two preboreal transgressions in southern Finland, the first about 9600-9500 BP and the second about 9200-9100 BP. More recently he has proposed that, in the area of $\mathrm{Hy}$ vinkää, southern Finland, the Ancylus transgression occurred at about 9600-9200 BP (Synge 1982, Fig. 12). The Yoldia I transgression of Estonia and the first preboreal transgression discussed by Sygne (1981) correspond well with the dates for the Ancylus transgression in the Espoo - Salpausselkä area. The second preboreal transgression of Synge (1981) has been assigned the same date as the Ancylus transgression in the area east of Helsinki (Fig. $15)$.

What really caused the Ancylus transgression in the Baltic? Eronen (1976) postulates that rapid melting of the Scandinavian Ice Sheet caused a sudden and sychronous rise in the water level of the whole Baltic. On the basis of investigations by Fredén, Agrell (1979, pp. 229230) proposes that the first discharge of the Ancylus Lake at Degerfors in Central Sweden did not play such an important role as supposed earlier. There probably was no Svea river but, instead, a narrow sound, and the ocean and the Ancylus Lake were at the same level (Agrell 1979, pp. 229-230). According to Glückert and Ristaniemi (1982), the discharge channel of the Ancylus Lake (Svea river or narrow sound) in Central Sweden regulated the transgression/regression so that south of the $\mathrm{O}$ isobase for the transgression (running via the Third Salpausselkä - Degerfors) there was a transgression in the Ancylus Lake, and north of it a regression (Fig. 15).

The beginning of the transgression in the area of the southern Baltic is to be found below the level of the present Baltic. Königsson (1968) has dated the transgression maximum at Öland to about $8800 \mathrm{BP}$, i.e. clearly younger than in the area of Espoo - First Salpausselkä. 


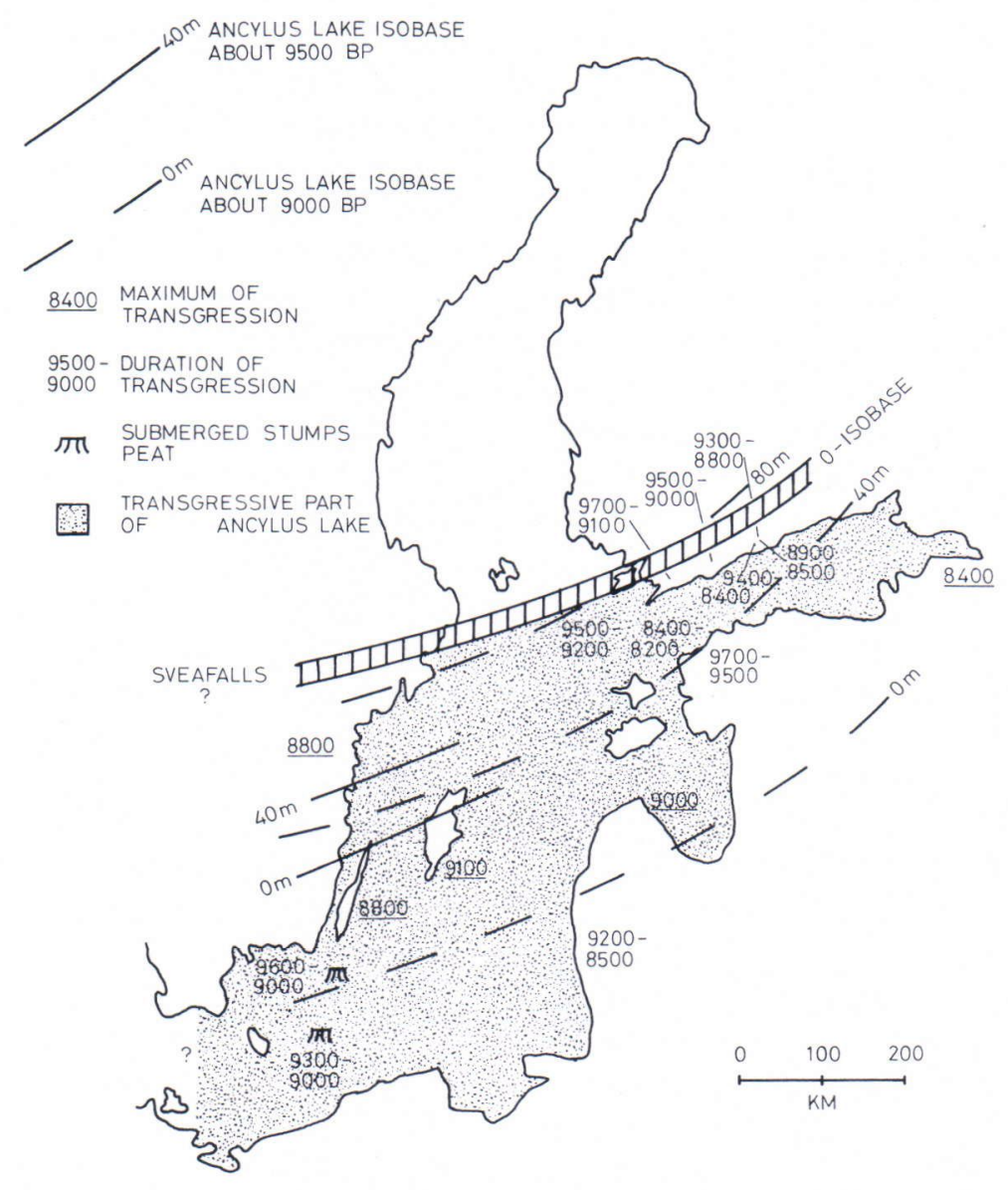

Fig. 15. Radiocarbon dates for the Ancylus transgression in different parts of the Baltic (collected from various sources).
The dates for the Ancylus transgression maximum differ from each other in different parts of the Baltic (Fig. 15). The differences in Fig. 15 in the dates for the maximum of the Ancylus transgression in different parts of the Baltic can be attributed to variations in uplift rate. The extent and rate of the Ancylus transgression also depended on the rate at which the ice sheet melted and the Degerfors threshold. The Degerfors area emerged from the sea at about 9000 BP (Fredén 1979, p. 68). This threshold regulated the level of the Baltic between 9600 and $9000 \mathrm{BP}$ in such a manner that north of the $\mathrm{O}$ isobase there was a continuous regression and south of it transgression. The threshold became dry because of the greater uplift in the northern part of the basin and of the transgressive water level of the Ancylus Lake, which caused continuous submergence of land in the southern part of the Baltic. At this time uplift raised the land above water level, first in SW Finland and, a little later, in SE Finland.

\section{Conclusions}

The Ancylus transgression of the Baltic has been studied in the area between the First Salpausselkä and Espoo, in southern Finland, with the aid of a sample series from 39 bog and lake basins. A transgression layer that can be visually observed has been found in eight basins; 
some of these transgression layers have been the subject of earlier publications (Glückert and Ristaniemi 1980, 1982; Ristaniemi 1984). The beginning of the transgression has been dated by ${ }^{14} \mathrm{C}$ to $9500 \mathrm{BP}$ and the end (maximum) to $9200 \mathrm{BP}$. According to these dates, the transgression appears to have occurred wholly during the Betula pollen zone, thus, a little earlier than suggested in investigations published in Finland before 1976.

The apparent amplitude of the transgression, which increases southeastwards or in the direction of smaller uplift, is about 6-7 $\mathrm{m}$ within the area of Espoo and about 4-5 $\mathrm{m}$ in the belt of the First Salpausselkä. We can assume that the transgression is visible in SW Finland up to the zone of the Third Salpausselkä, the culmination zone of the transgression, which has also been marked as the $\mathrm{O}$ isobase for the transgression (Glückert and Ristaniemi 1982; Ristaniemi 1984).

In the present study we obtained different dates for pollen zone boundary $\mathrm{P}$ with the radiocarbon method (see Figs. 12-13). These dates agree neither with those presented in earlier publications nor with some of the results of the present study.

In transgression basins, the discrepancy between the radiocarbon and pollen analytical

\section{References}

Agrell, H. 1979. The Quaternary History of the Baltic. Sweden In Gudelis, V. \& Köningsson, L.-K. (Eds.) The Quaternary History of the Baltic. Acta Univ. Ups. Symp. Univ. Ups. Ann. Quing. Cel. 1, Uppsala, pp. $219-239$.

Alhonen, P. 1971. The stages of the Baltic Sea as indicated by the diatom stratigraphy. Acta Bot.Fennica 76 .

-, \& Haavisto, M.-L. 1969. The biostratigraphical history of Lake Otalampi in southern Finland, with special reference to the remains of subfossil midge fauna. Bull.Geol.Soc. Finland 41, 157-164.

Berglund, B. E. 1964. The Post-glacial shore displacement in eastern Blekinge, southeastern Sweden. Sver. Geol. Unders. C 599, 47p. dates can be attributed to several factors: e.g., - transgression beginning at different times in different basins, mainly depending on the altitude of the threshold of the basins;

- mixing of the transgression material, thus changing the pollen relations;

- differential uplift, but this is difficult to observe and take into account.

The marked dispersion of radiocarbon and pollen analytical dates indicates that pollen zone boundary $\mathrm{P}$ cannot be regarded as synchronous within the area studied, probably not even throughout southern Finland. The results indicate clearly that at least zone boundary $\mathrm{P}$ must be determined separately for each area and in each basin studied. In the present study area, the date for the Betula/Pinus zone boundary is about $9300-9200 \mathrm{BP}$, thus a little older than that given earlier for southern Finland.

Acknowledgements, We wish to thank Mr Hannu Venho for help in the field and laboratory work, Miss Tuovi Kankainen and her staff for the radiocarbon dates, Dr. Risto Tynni for testing and correcting the diatoms, Assistant Professor Matti Saarnisto for commenting on the manuscript, and the Academy of Finland for financial assistance channelled through the Finnish National IGCP Committee.

Cleve-Euler, A. 1951-1955. Die Diatomeen von Schweden und Finnland I-V. Kungl.Svenska Vetenskapsakademiens Handlingar 4. Ser. 2:1 (1951), 3:3 (1952), 4:1, 5 (1953), 5:4 (1955).

Donner, J. 1952. On the early Post-glacial shoreline displacement in south-east Finland. Ann.Acad.Sci.Fennicae, A III, 29, 22 p.

-, 1971. Towards a stratigraphical division of the Finnish Quaternary. Soc.Sci.Fennica, Comm.Phys.-Math. 41, $281-305$.

-, \& Gardemeister, R. 1971. Redeposited Eemian marine clay in Somero, South-western Finland. Bull.Geol.Soc. Finland 41, 1, 73-88.

-, Alhonen, P.; Eronen, M.; Jungner, H. \& Vuorela, I. 1978. Biostratigraphy and radiocarbon datings of the Holocene lake sediments of Työtjärvi and the peats in the 
adjoining bog Varrassuo west of Lahti in southern Finland. Ann.Bot.Fennici 15, 258-280.

-, \& Eronen, M. 1981. Stages of the Baltic Sea and Late Quaternary Shoreline Displacement in Finland. Excursion Guide. INQUA, Subcommission on Shorelines of Northwestern Europe. Univ. Helsinki, Dept. Geol., Div. Geol. Palaeontol., Stencil No. 5, 53 p.

Erdtman, G. 1943. An Introduction to Pollen Analysis. Waltham, Mass., U.S.A., 239 p.

-, Berglund, B.\& Praglowski, J., 1961. An Introduction to a Scandinavian Pollen Flora. Almqvist \& Wiksell, Stockholm, 92 p.

Eronen, M., 1974. The history of the Litorina Sea and associated Holocene events. Soc.Sci.Fennica, Comm.Phys.- Math. 44, 79-195.

-, 1976, A radiocarbon-dated Ancylus transgression site in south-eastern Finland. Boreas 5, 65-76.

-, \& Haila, H. 1982. Shore displacement during the Ancylus Lake stage near Helsinki, South Finland. Ann. Acad.Sci.Fennicae, A III, 132.

Faegri, K. \& Iversen, J., 1975. Textbook of pollen analysis. Munksgaard, Copenhagen, 195 p.

Florin, M. 1977. Late-Glacial and Pre-boreal Vegetation in Southern Central Sweden. II. Pollen, Spore and Diatom Analyses. Striae 5, $60 \mathrm{p}$.

Fredén, C., 1979. The Quaternary History of the Baltic. The Western Part. In: Gudelis, V. \& Königsson, L.-K. (Eds.) The Quaternary History of the Baltic. Acta Univ. Ups. Symp. Univ. Ups. Ann. Quing. Cel. 1, Uppsala, pp. 59-74.

Glückert, G., 1970. Vorzeitliche Uferentwicklung am Ersten Salpausselkä in Lohja, Südfinnland. Ann.Univ. Turkuensis A II, 45, 116 p.

-, 1976. Post-Glacial shore-level displacement of the Baltic in SW-Finland. Ann.Acad.Sci.Fennicae A III, $118,92 \mathrm{p}$.

-, 1979. Itämeren ja metsien historia Salpausselkävyöhykkeessä Uudenmaan länsiosassa. Publ.Dept.Quaternary Geol., Univ.Turku 39, 77 p.

-, \& Ristaniemi, O., 1980. Ancylustransgressio Karjalohjalla Toisella Salpausselällä. Publ.Dept.Quaternary Geol., Univ.Turku 41, 22 p.

- \& Ristaniemi, O. 1982. The Ancylus transgression west of Helsinki, South Finland. A preliminary report. Ann.Acad.Sci.Fennicae III, 132, 99-100.

Gudelis, V. 1979. The Quaternary History of the Baltic. Lithuania. In Gudelis, V. \& Köningsson, L.-K., (Eds.), The Quaternary History of the Baltic. Acta Univ. Ups. Symp. Univ. Ups. Ann. Quing. Cel. 1, Uppsala, pp. 159-173.

Haila, H., 1982. Ancylusjärven rannansiirtyminen Helsingin lähellä. Geologi 34, 8 .

Hustedt, F., 1930: Bacillariophyta (Diatomeae). Pascher: Süsswasserflora, 10. Jena, 465 p.
Hyde, H.A. \& Adams, K.F., 1958: An Atlas of Airborne Pollen Grains. Mac Millan \& Co Ltd, London, 159 p.

Hyуррӓ, E., 1932: Die Postglazialen Niveauverschiebungen auf der karelischen Landenge. Fennia 56, 1, 241 p.

-, 1937: Post-glacial changes of shore-line in South Finland. Bull.Comm.Géol.Finlande 120, 225 p.

-, 1942: Beiträge zur Kenntnis der Ladoga- und Ancylustransgression. Bull.Comm.Géol.Finlande 128, 138178.

Kessel, H. and Raukas, A., 1979: the Quaternary History of the Baltic, Estonia. In Gudelis, V. \& Königsson, L.-K. (Eds.) The Quaternary History of the Baltic, Acta Univ. Ups. Symp. Univ. Ups. Ann. Quing. Cel. 1, Uppsala, pp. 127-146.

Königsson, L.-K., 1968: The Ancylus transgression in the Skede Mose area, Öland. Geol. Fören. Stockh., Förh. $90,5-36$.

Mangerud, J. Andersen, S.T.; Berglund, B.E. \& Donner, J. 1974: Quaternary stratigraphy of Norden, a proposal for terminology and classification. Boreas 3, 109-128.

Mölder, K., 1955: Die Entwicklungsgeschichte des Sees Siikajärvi im mittleren Uusimaa. Acta Geogr. 14, $300-313$.

-, \& Tynni, R., 1967-1973: Die rezente und subfossile Diatomeen in Finnland I-VII. Bull.Comm. Géol. Finlande 29, 199-217; Bull. geol. Soc. Finland 40, $151-170 ; 41,235-251 ; 42,129-144 ; 43,203-220 ; 44$, 141-149; 45, 159-179.

-, Valovirta, V.\& Virkkala, K., 1957: Über Spätglazialzeit und frühe Postglazialzeit in Südfinnland. Bull.Comm. Géol.Finlande 178, 49 p.

Mörner, N.-A., 1979: The Fennoscandian Uplift: geological data and their geodynamical implication. In Mörner, N.-A. (Ed.), Earth Rheology, Isostasy and Eustasy, Wiley, pp. 251-284.

Nilsson, E., 1968: Södra Sveriges senkvartära historia. Summary: The Late-Quaternary History of southern Sweden. K. Sven. Vetenskapsakad. Handl. 12 (1) 117 p.

Olsson, I., 1979. A warning against radiocarbon dating of samples containing little carbon. Boreas 8, 203-207.

Persson, C., 1979. Shore displacement during Ancylus time in the Rejmyra area south central Sweden. Sver. Geol. Unders., C 755, 23 p.

Ristaniemi, O., 1984. Ancylusjärven aikainen rannansiirtyminen Salpausselkävyöhykkeessä Karjalohjan-Kiskon alueella Lounais-Suomessa. Publ.Dept.Quaternary Geol., Univ.Turku, 53, 75 p.

Saarnisto, M., 1970. The Late Weichselian and Flandrian History of the Saimaa Lake Complex. Soc. Sci. Fennica, Comm.Phys.-Math. 37, 107 p.

Salmi, M., 1948. Die Ancylustransgression in dem Moore Hangassuo in Süd-Finnland. Bull.Comm.Géol.Finlande $142,20 \mathrm{p}$. 
Sauramo, M., 1953. Ancylusjärven arvoitus ja sen ratkaisu. Suomen museo, $33 \mathrm{p}$.

-, 1954. Das Rätsel des Ancylussees. Geol. Rundsch. 42, 197-223.

-, 1958. Die Geschichte der Ostsee. Ann.Acad. Sci.Fennicae A III, 51, $522 \mathrm{p}$.

Synge, F.,1981. Late Glacial shorelines in South Finland. Geol. Surv. Finland, Rep. Invest. 46, 29.

-, 1982. A new shoreline chronology for the Salpausselkäs. Ann.Acad.Sci.Fennicae A III, 134, 29-60.
Tynni, R., 1966. Über spät- und postglaziale Uferverschiebung in der Gegend von Askola, Südfinnland. Bull.Comm. Géol. Finlande 223, 97 p.

-, 1975-1981. Über die rezente und subfossile Diatomeen in Finnland VIII-XI. Geol.Surv. Finland, Bull. 274, 55 p., 284, 37 p., 296, 55 p., 312, 93 p.

Valovirta, V., 1965. Zur spätquartären Entwicklung SüdostFinnlands. Bull.Comm.Géol.Finlande 220, 101 p.

Manuscript received May 8, 1985 